\title{
Original Paper / Artigo Original \\ Boraginales (Boraginaceae s.l.) and Lamiales (Lamiaceae and Verbenaceae) in a Conservation Area in the Semiarid Region of Northeastern Brazil
}

\author{
Francisco Carlos Pinheiro da Costa ${ }^{1,3}$ \& José Iranildo Miranda de Melo ${ }^{2,3,4}$
}

\begin{abstract}
A taxonomic treatment for Boraginales (Boraginaceae s.l.) and Lamiales (Lamiaceae and Verbenaceae) in the Engenheiro Avidos Ecological Park, a full-protection reserve located in the semiarid region of Paraíba State in northeastern Brazil is presented in this study. At the Park, a total of 22 species were encountered, including nine species of Boraginaceae s.l., six species of Lamiaceae, and seven species of Verbenaceae. Vitex orinocensis (Lamiaceae) was found for the first time for Caatinga and also represents a new record for Paraíba state. Morphological descriptions, keys for separating the families and respective species; data concerning flowering, fruiting, geographic distributions, and of the preferred habitats of the species found in the study area are also provided.

Key words: Brazil, caatinga, floristics, Lamiales, taxonomy.

Resumo

O presente estudo apresenta o tratamento taxonômico de Boraginales (Boraginaceae s.l.) e Lamiales (Lamiaceae e Verbenaceae) do Parque Ecológico Engenheiro Avidos, Unidade de Conservação do semiárido da Paraíba, nordeste brasileiro. No Parque foram encontradas 22 espécies, incluindo nove de Boraginaceae s.l., seis de Lamiaceae e sete de Verbenaceae. Vitex orinocensis (Lamiaceae) foi encontrada pela primeira vez para a Caatinga e também representa o primeiro registro para o estado da Paraíba. Foram elaboradas descrições morfológicas, chaves para separação das famílias e respectivas espécies, além de fornecidos dados de floração, frutificação, distribuição geográfica e dos ambientes preferenciais das espécies encontradas.

Palavras-chave: Brasil, caatinga, florística, Lamiales, taxonomia.
\end{abstract}

\section{Introduction}

Boraginaceae Juss. in their traditional circumscription is a cosmopolitan family, widely distributed in tropical, subtropical and temperate regions, the temperate zone of the Northern Hemisphere and the Mediterranean being its main centers of diversity (Al-Shehbaz 1991). It is composed of approximately 2,700 species subordinated to 130 genera (Vieira et al. 2015). In Brazil, it is represented by 11 genera and 135 species, of which 61 are endemic (BFG 2018).
Their species present varied habits, from small herbs to large trees (Al-Shehbaz 1991). According to Melo \& Andrade (2007), its leaves are commonly simple, alternate, and sometimes subopposite. The flowers are aggregated in paucifloras or multifloras inflorescences or rarely solitary, positioned in the axillary or supra-axillary region. The fruit is drupaceous, with one or two pyrene, or schizocarp, with two or four nutlets, and constitutes an important character for the delimitation of its genera and species (Johnston 1930).

\footnotetext{
${ }^{1}$ Universidade Federal de Campina Grande, Centro de Formação de Professores, Lab. Botânica, R. Sérgio Moreira de Figueiredo sn, 58900-000, Cajazeiras, PB, Brasil.

${ }^{2}$ Universidade Estadual da Paraíba, Centro de Ciências Biológicas e da Saúde, Depto. Biologia, R. Baraúnas 351, 58429-500, Campina Grande, PB, Brasil.

${ }^{3}$ Universidade do Estado da Bahia, Depto. Educação, Prog. Pós-graduação em Biodiversidade Vegetal, Campus VIII, 48608-240, Paulo Afonso, BA, Brasil.

${ }^{4}$ Corresponding author: tournefort@gmail.com
} 
Lamiaceae Martinov is one of the largest families of Angiosperms and also one of the most economically important. According to Harley (2012), there are estimated 240 genera that gather 7,200 species, occurring in both temperate and tropic regions. They are found mainly in savanna formations (open areas) and in mountainous regions, developing especially in the Mediterranean region (Harley \& Reynolds 1992). It is morphologically characterized by quadrangular branches, opposite leaves with serrated margin, often aromatic, and usually zigomorphic flowers of bilabiate corolla (Harley 1996). The family is represented in Brazil by 525 species, of which 344 are endemic (BFG 2018).

Verbenaceae J. St.-Hil. is a Pantropical distribution family, with main center of diversity in the neotropics, especially in South America, but with representatives in the temperate zones of the Northern Hemisphere (Marx et al. 2010). Their representatives presents undetermined racemes, spikes or glomerulus, ovules adhered to the margins of the false septum, simple style with 2-lobed stigma, extinguished pollen close to openings and unicellular, non-glandular trichomes, which allows distinguishing it from Lamiaceae with which shares some morphological characteristics Judd et al. (2009). Verbenaceae comprises approximately 1,000 species of which 279 species can be found in Brazil being that 179 are endemics (BFG 2018).

The present study considered the former circumscription of Boraginaceae s.l. (APG III 2009;
Cohen 2013), while Lamiaceae and Verbenaceae were treated based on the current circumscriptions attributed to both (APG IV 2016).

The EAEP (Engenheiro Avidos Ecological Park) is a complex of mountain ranges between the municipalities of Cajazeiras and São José de Piranhas, in the upper Sertão of the Paraíba state. EAEP is considered a priority area for the conservation of the biodiversity of Paraíba. Despite this, little is known about its plant biodiversity. In this context, the present study focuses on the taxonomic diversity of Boraginaceae, Lamiaceae and Verbenaceae families in EAEP, aiming to increase the knowledge of vegetal biodiversity in Alto Sertão, and this approach will also allow subsidizing the conservation activities of the Ecological Park.

\section{Materials and Methods}

The Engenheiro Avidos Ecological Park (EAEP) is located in the municipalities of Cajazeiras and São José de Piranhas, Alto Sertão region of the Paraíba State, Northeastern Brazil $\left(06^{\circ} 50^{\prime}-7^{\circ} 25^{\prime} \mathrm{S}\right.$ and $\left.38^{\circ} 10^{\prime}-38^{\circ} 40^{\prime} \mathrm{W}\right)$ and occupies an area of approximately 182 ha (Figs. 1-2) (PAE-PB 2011). The Park is situated in a Brejo de Altitude area, in the semiarid region of Paraíba, and include a remnant of Caatinga (deciduous thorn scrub and low arboreal vegetation) of high biological importance, with enclaves of montane and sub-montane seasonal vegetation. The predominant climate in the region of the EAEP is classified as semiarid, with 7 to 8 dry months, and

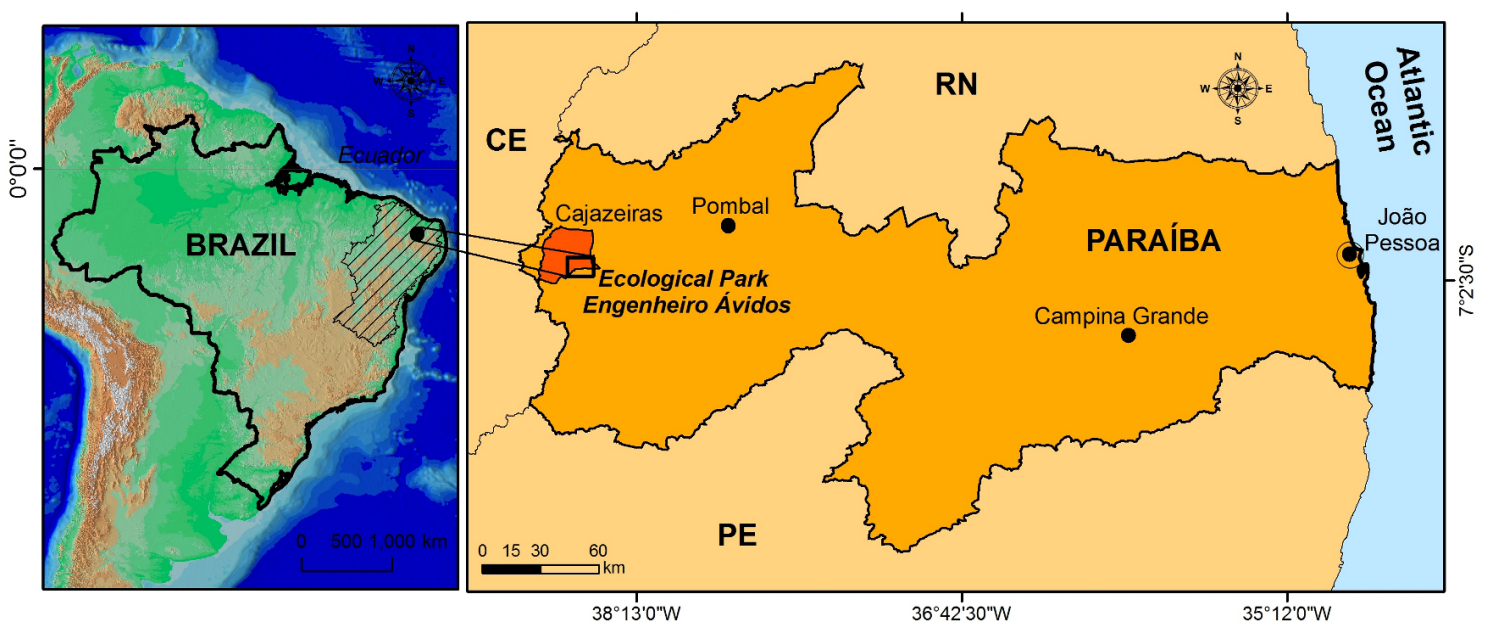

Figure 1 - Location of the study area, the Engenheiro Avidos Ecological Park, Cajazeiras, Paraíba state, Brazil (source: Laboratório de Geomorfologia da UFRN, Campus Caicó). 

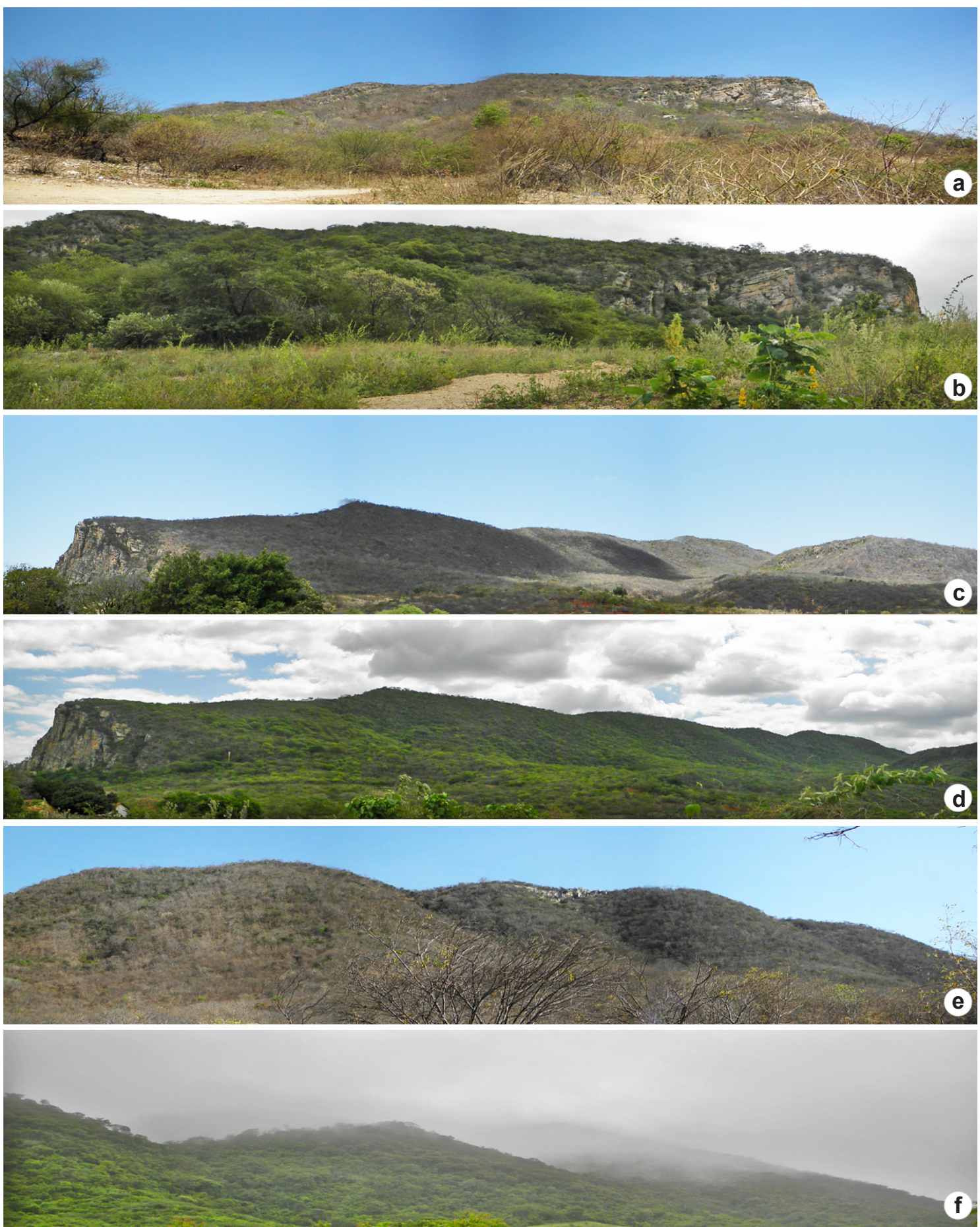

Figure 2 - $a-b$. windward slope of the Engenheiro Avidos Mountain - a. dry season. b. rainy season. c-d. windward slope of the Frade Mountain - c. dry season. d. rainy season. e-f. lee side of the Engenheiro Avidos Mountain - e. dry season. f. rainy season. 
irregular distribution of the annual precipitation, which rarely exceeds $900 \mathrm{~mm}$; the mean annual temperature is $28{ }^{\circ} \mathrm{C}$ (Alvares et al. 2014). The area soils are of low to medium fertility, and the elevation there varies from 300 to $700 \mathrm{~m}$ a.s.l. (EMBRAPA 2007).

Collections were carried out every two weeks for one year (May/2014 to June/2015) in the rainy and dry seasons, exploring all the environments of the EAEP by the method of walking (Filgueiras et al. 1994) The collections obtained during the fieldwork were incorporated into the herbaria of the Universidade do Estado da Bahia (HUNEB), Campus VIII, Coleção Paulo Afonso, Bahia, and the Universidade Estadual da Paraíba (ACAM), Campus I, Campina Grande, Paraíba (not indexed). All acronyms follow Thiers (continuously updated). Genera and species names were assigned based on the specialized literature for the families Boraginaceae s.l., Lamiaceae, and Verbenaceae (Almeida \& Albuquerque 2002; Atkins 2005; Cavalheiro et al. 2011; Harley 2012; Lima \& França 2007, 2009; Melo \& Semir 2008; 2010; Santos et al. 2012; Silva \& Lima 2012).

Morphological descriptions, keys to the families and their respective genera and species, information concerning flowering, fruiting, geographic distributions, and the preferred habitats of the species are provided. The morphological descriptions were based on the specimens collected in the study area. The morphological descriptions were based on the specimens collected in the study area; the specialized literature was consulted to standardize the descriptions (Radford et al. 1974; Hickey \& King 2000).

\section{Results and Discussion}

\section{Key to identification of the families Boraginaceae, Lamiaceae, and Verbenaceae in the Ecological Park of Engenheiro Avidos}

1. Alternate leaves, rarely opposite; stamens 5 Boraginaceae

1'. Opposite leaves, rarely alternate; stamens 4, rarely 2 plus 2 staminoids.

2. Corolla generally bilabiate; style generally bifurcated; trichomes multicellular, rarely unicellular Lamiaceae

2' Corolla generally hypocrateriform or infundibuliform; Simple style; trichomes unicellular, rarely multicellular Verbenaceae

Boraginaceae, Gen. Pl.: 128. 1789.

The Boraginaceae family is represented in the Engenheiro Avidos Ecological Park by five genera and nine species: Cordia trichotoma (Vell.) Arráb. ex Steud., Euploca lagoensis (Warm.) Diane \& Hilger, Euploca humilis (L.) Feuillet, Euploca procumbens (Mill.) Diane \& Hilger, Heliotropium angiospermum Murray, Heliotropium elongatum (Lehm.) I.M.Johnst., Myriopus salzmannii (DC.) Diane \& Hilger, Varronia curassavica Jacq. and Varronia leucomalloides (Taroda) J.S.Mill.

Among species registered for the Ecological Park, only V. leucomalloides is endemic to Brazil, and has a restricted distribuition to the Northeastern region, in the Caatinga domain (BFG 2018). All others are widely distribuited, occurring among the South region of North America to South America (E. lagoensis, E. humilis, E procumbens, $H$. angiospermum and $V$. curassavica) or restrict to South America (C. trichotoma, H. elongatum and M.salzmannii). In comparison with other study carried out in Paraíba state about Boraginaceae family, the richness of species in the EAEP (nine species) was highest (Melo et al. 2011) conducted in the Enviromental Protection Area of the Onças (five species), where only three species were common on both areas: E. procumbens, $H$. angiospermum, and H. elongatum.

\section{Key to identification of the species of Boraginaceae in the Ecological Park of Engenheiro Avidos}

1. Branches with stellate trichomes; inflorescences paniculiform 1. Cordia trichotoma

1'. Branches with simple trichomes; inflorescences spiciform, glomerule-globose, scorpioid or rarely solitary flowers.

2. Inflorescences spiciform or glomerule-globose; style bipartite, stigmas 4 . 
3. Abaxial face leaf blade pubescent to tomentose; calyx pubescent externally

8. Varronia curassavica

3'. Abaxial face leaf blade floccose; calyx floccose externally 9. Varronia leucomalloides

2'. Inflorescences scorpioid or flowers solitary; style entire or obsolete, stigma 1.

4. Branches with lenticels; fruit drupaceous 7. Myriopus salzmannii

4'. Branches without lenticels; fruit schizocarpic.

5. Anthers fused at their apex; fruit with 4 nutlets.

6. Flowers solitary; fruit piriform, with uncinate trichomes 2. Euploca lagoensis

6'. Inflorescence scorpioid; fruit subglobose to globose, trichomes uncinate absent.

7. Blade chartaceous, venation hyphodromous; fruit globose, villous 3. Euploca humilis

7'. Blade subsucculent, venation eucamptodromous; fruit subglobose, sericeous ....... 4. Euploca procumbens

5'. Anthers free among themselves; fruit with 2 nutlets.

8. Petiole partially alate; fruit mitriform, costate 6. Heliotropium elongatum

8'. Petiole attenuated; fruit flattened-globose, verrucose

5. Heliotropium angiospermum

1. Cordia trichotoma (Vell.) Arráb. ex Steud., Nomencl. Bot. 1: 419. 1840.

Tree, 4-10 m tall. Branches pubescent, trichomes stellate, lenticels whitish. Leaves alternate; petiole $0.2-3 \mathrm{~cm}$ long, pubescent to sericeous; blade 3-12.7 × 1.2-4.5 cm, chartaceous to semicoriaceous, oval, obovate to elliptic, apex acute to acuminate, margin entire, base cuneate, rarely rounded or oblique, adaxial face strigose to glabrescent, ferruginous, abaxial face pubescent, trichomes stellate; venation eucamptodromous. Inflorescences paniculate, terminal. Flowers 1.5-2 cm long; pedicel ca. $2 \mathrm{~mm}$ long, tomentose; calyx ca. $1 \mathrm{~cm}$ long, tubular, costate, externally tomentose, internally sericeous, lacinias $1.5-2 \times 0.5-1 \mathrm{~mm}$, oval-lanceolate, apex slightly mucronate; corolla ca. 1.4-1.8 cm long, hypocrateriform, white, brown when old, marcescent, glabrous, tube ca. $0.7-1 \mathrm{~cm}$ long, lobes $0.8-1 \times 0.5-0.7 \mathrm{~cm}$, oblong, patent, apex subtruncate; stamens 5 (-6), free, inserted to ca. $0.5-0.7 \mathrm{~cm}$ long from the base of the tube, filaments ca. $0.5-1 \mathrm{~cm}$ long, brown, pubescent at base, anthers $2-3.5 \times 0.8-1$ $\mathrm{mm}$, oblong to lanceolate, apex acute; ovary ca. $2 \mathrm{~mm}$ diam., subglobose, glabrous, style ca. $1 \mathrm{~cm}$ long in brevistylous flowers, ca. $1.5 \mathrm{~cm}$ long in longuistylous flowers; ca. stigmas $1.5-2.5 \mathrm{~mm}$ long, foliaceous, narrow, glabrous.

Examined material: Cajazeiras, Parque Ecológico Engenheiro Avidos, margem Oeste do açude Engenheiro Avidos, beira da estrada próxima à Prainha, 8.VIII.2015, bud and f1., F.C.P. Costa 112 (ACAM).

Cordia trichotoma is a South American species, occurring in northeastern Argentina, eastern Paraguay and Bolivia, and in all regions of Brazil, associated with Amazonian, Cerrado, and Caatinga vegetation (BFG 2018; Vieira et al. 2015). Encountered along roadsides, associated with shrub-Caatinga on clayey soils. Flowering in August.

This species is easily recognized by branches with stellate trichomes, paniculate inflorescence, calyx tubular and costate, and corolla lobes oblong with subtruncate apex.

2. Euploca lagoensis (Warm.) Diane \& Hilger, Bot. Jahrb. Syst. 125(1): 48. $2003 . \quad$ Fig. 3a

Herb, 10-15 cm tall, decumbent. Branches glaucous, sericeous. Leaves alternate; petiole ca. $1 \mathrm{~mm}$ long, glabrous; blade $0.8-1 \times 0.2-0.3 \mathrm{~cm}$, subsucculent, narrowly elliptic to oblong-elliptic, apex acute, margin entire, slightly revolute, ciliate, base attenuated, adaxial and abaxial faces sericeous; venation hyphodromous. Flowers solitary, supraaxillary, 6-7.5 mm long; pedicel $1-1.5 \mathrm{~mm}$ long, sericeous; calyx partially united, lacinia $2-2.5$ $\times 0.3-0.5 \mathrm{~mm}$, narrowly ovate to ovate, margin ciliate, externally sericeous, internally glabrescent; corolla 4-5 mm long, tubular to infundibuliform, white, inner perianth yellow, externally puberulous, internally glabrescent, tube ca. $2 \mathrm{~mm}$ long, lobes 1.5-2 mm long, elliptic; stamens sessile; anthers ca. $0.7 \mathrm{~mm}$ long, fused at apex, ovate, barbate apically; ovary ca. $1 \mathrm{~mm}$ long, subglobose; style 1, entire, stigma 1, ca. $0.3 \mathrm{~mm}$ long, subsessile, conical. Schizocarp, ca. $2 \mathrm{~mm}$ diam., piriform, rostrate, sulcate, nutlets 4 , ca. $1.5 \mathrm{~mm}$ diam., trigonous, trichomes uncinate. Seeds ca. $1.4 \mathrm{~mm}$ long, elliptic. 

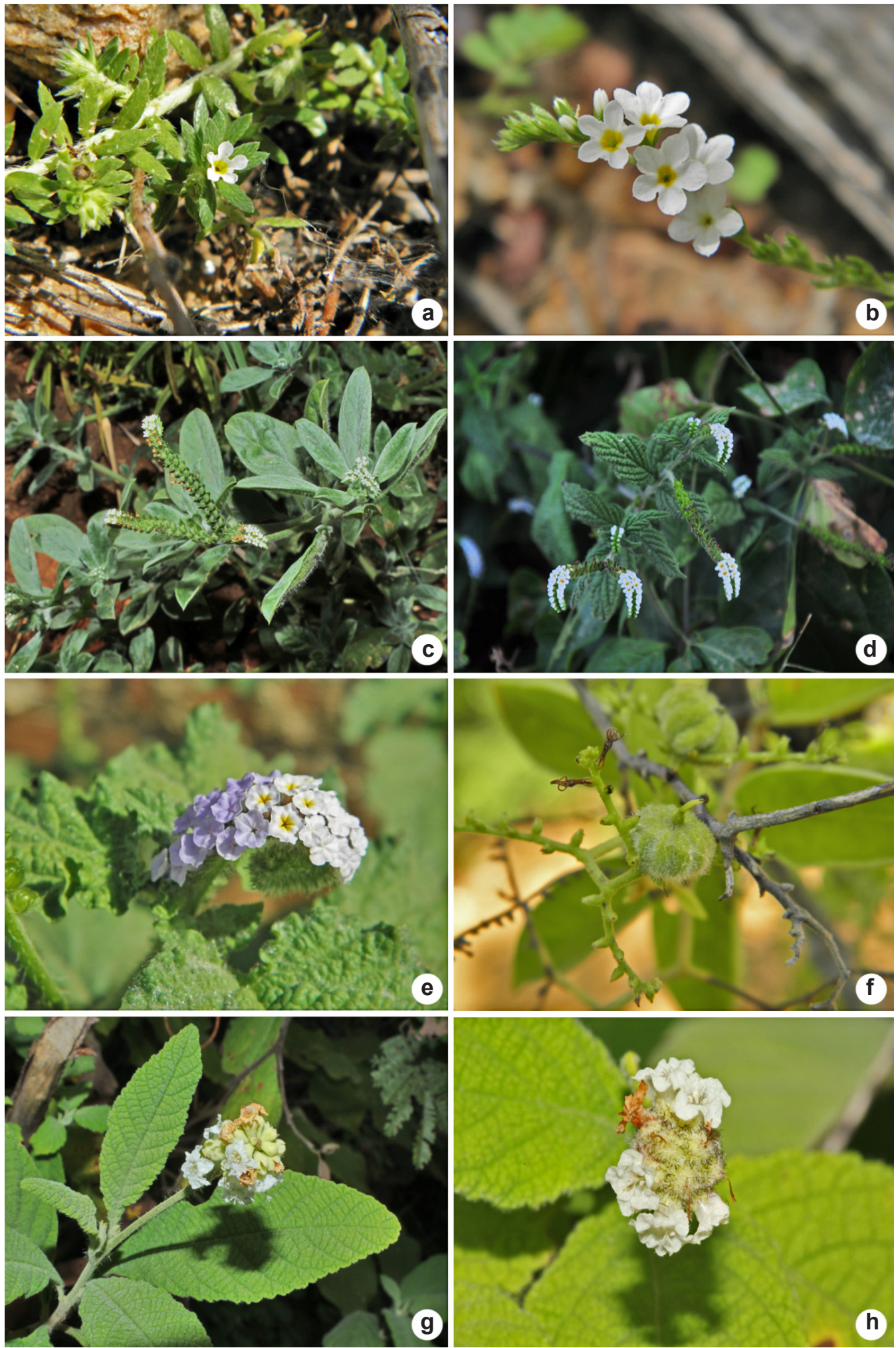

Figure 3 - a. Euploca lagoensis - habit. b. E. humilis - inflorescence. c. E. procumbens - habit. d. Heliotropium angiospermum - habit. e. H. elongatum - detail of the inflorescence. f. Myriopus salzmannii - reproductive branch, showing a fruit. g. Varronia curassavica - inflorescence. h. V. leucomalloides - inflorescence. 
Examined material: Cajazeiras, Parque Ecológico Engenheiro Avidos, Prainha, margem Oeste do açude Engenheiro Avidos, 11.XII.2014, fl. and fr., F.C.P. Costa 68 (HUNEB); 8.I.2015, fl. and fr., F.C.P. Costa 89 (ACAM).

Euploca lagoensis occur from Mexico to southeastern Brazil (Melo \& Semir 2010). It has been collected in the states of Ceará, Paraíba, Piauí, and Rio Grande do Norte in northeastern Brazil associated with Caatinga and Cerrado vegetation and caatinga-cerrado transition zones (BFG 2018). It was found in the EAEP in a periodically flooded area with stony soil. According to Melo \& Semir (2010), this species is commonly encountered at the edges of rivers and lakes, in the dry beds of temporary lakes, and in periodically flooded sites. Flowering and fruiting from December to February.

This species is easily recognized by its supraaxillary solitary flowers, by having elliptic corolla lobes, and fruits that are piriform, sulcate, rostrate, and have uncinate trichomes.

3. Euploca humilis (L.) Feuillet, PhytoKeys 61: 104. 2016. Fig. $3 b$

Herb, 10-30 cm tall, erect or semiprostrate. Branches glaucous to brownish, hirsute to sericeous. Leaves alternate to subopposite; petiole ca. 1.2-2.6 mm long, sericeous; blade 1.5-2.5 $\times$ $0.2-0.5 \mathrm{~cm}$, chartaceous, lanceolate to linear, apex acute, margin entire, revolute, base attenuated to sharp, adaxial face hirsute to sericeous, abaxial face tomentose; venation hyphodromous. Inflorescences scorpioid, terminal and axillary; bracts 3-4.5 $\times$ 0.5-1 mm, narrowly elliptic to lanceolate, margin ciliate, slightly revolute, externally and internally sericeous. Flowers ca. $5 \mathrm{~mm}$ long, subsessile; calyx with lacinias of different sizes $0.8-1.4 \times$ 0.6-0.8 $\mathrm{mm}$, oval to lanceolate, margin ciliate, externally sericeous, internally glabrescent; corolla 5-5.5 mm long, tubular-salveform, white, inner perianth yellow, sericeous externally, trichomes short with blackish apex internally, tube ca. 2.5-3 mm long, lobes ca. 1.3-2.1 mm long, oval, apex slightly cuspidate; stamens subsessile, anthers ca. $1 \mathrm{~mm}$ long, fused at apex, ovate, barbate apically; ovary ca. $0.5 \mathrm{~mm}$ long, globose, glabrous; style 1 , entire, ca. $0.2 \mathrm{~mm}$ long, terminal; stigma 1, ca. 0.5 $\mathrm{mm}$ long, narrowly conical. Schizocarp, ca. $2 \mathrm{~mm}$ diam., globose, nutlets 4 , with ca. $1 \mathrm{~mm}$ diam., villous, trichomes uncinate absent.

Examined material: São José de Piranhas, margem da estrada, próximo a córrego, sentido sítio Frade, 7.I.2015, fl. and fr., F.C.P. Costa 73 (HUNEB); 25.III.2015, fl. and fr., F.C.P. Costa 85 (ACAM); área antropizada e pastoreada, sentido sítio Frade, 28.VII.2015, fl. and fr., F.C.P. Costa 144 (UFCG-CFP).

Euploca humilis is distributed through Mexico, the Antilles, British Guyana, and Venezuela (Melo \& Semir 2010); it has been recorded in the central western, northeastern and southeastern Brazil. This species associated with hypo and hyperxerophytic Caatinga, cerradão, Campos rupestres vegetation, and Caatinga-Cerrado transition zones, being commonly encountered in clayey and sandy soils, as well as on rock outcrops (Melo \& Semir 2010). It was collected in open areas with clayey soils near the reservoir at the EAEP, forming large populations. Flowering and fruiting in January, March, and July.

This species can be recognized by its bracts narrowly elliptic to lanceolate, corolla lobes oval, and fruit densely villous.

4. Euploca procumbens (Mill.) Diane \& Hilger, Bot. Jahrb. Syst. 125(1): 48. $2003 . \quad$ Fig. 3c Herb, $10-40 \mathrm{~cm}$ tall, erect or prostrate. Branches sericeous. Leaves alternate; petiole 3-5 mm long, sericeous; blade 1.6-2.2 × 0.7-1 $\mathrm{cm}$, subsucculent, obovate to elliptic, apex acute, apiculate, margin entire, base sharp to attenuated, sericeous on both faces; venation eucamptodromous. Inflorescences scorpioid, terminal and axillary. Flowers 2-2.5 $\mathrm{mm}$ long, subsessile; calyx 1.2-1.7 mm long, externally strigose, internally sericeous, lacinias $0.7-1.4 \mathrm{~mm}$ long, oval-lanceolate, apex acute; corolla 2-2.2 $\mathrm{mm}$ long, tubular-hypocrateriform, white, inner perianth yellow, externally sericeous, internally glabrous, tube 1-2 mm long, lobes $0.4-0.6 \mathrm{~mm}$ long, obovate, patent, apex acute to obtuse; stamens subsessile, anthers ca. $0.5 \mathrm{~mm}$ long, fused at apex, oval-lanceolate, barbate apically; ovary ca. $0.5 \mathrm{~mm}$ long, globose, pubescent to sericeous; style obsolete; stigma 1, ca. 0.3-0.5 mm long, conical, pubescent. Schizocarp, ca. $1 \mathrm{~mm}$ diam., subglobose, sericeous, nutlets 4, with 1 seed each, trichomes uncinate absent.

Examined material: Cajazeiras, Parque Ecológico Engenheiro Avidos, margem oeste do açude Engenheiro Avidos, 14.X.2014, fl. and fr., F.C.P. Costa 46 (HUNEB); 11.XII.2014, fl. and fr., F.C.P. Costa 72 (UFCG-CFP); margem da estrada próximo à vila DNOCS, 21.XI.2014, fl. and fr., F.C.P. Costa 59 (ACAM).

Euploca procumbens is widely distributed in the Americas from southern United States to Argentina, as well as the Antilles (Melo 
2012). It can be found in all phytogeographic domains in northern, northeastern, central western, southeastern and southern Brazil (BFG 2018). It was encountered along roadsides and at the edges of the reservoir in the study area. Flowering and fruiting in October through December.

This species can be easily recognized by its ashen branches covered by a sericeous indument, leaves subsucculent, corolla lobes obovate, and stigma pubescent and sericeous fruits.

5. Heliotropium angiospermum Murray, Prod. Stirp. Gotting. 217. 1770.

Fig. 3d

Subshrub, 10-40 cm tall; branches scabrous to hirsute. Leaves alternate to subopposite; petiole ca. $0.6-1.3 \mathrm{~cm}$ long, attenuated, estrigose to hirsute; blade $7.3-10.3 \times 3.2-3.9 \mathrm{~cm}$, membranaceous, oval to elliptic, apex acute to acuminate, margin entire, ciliate, base attenuated, adaxial face sparsely strigose, abaxial face strigose to tomentose; venation eucamptodromous. Inflorescences scorpioid, falsely terminal and axillary; peduncle $2.3-6.5 \mathrm{~cm}$ long, strigose. Flowers 3-4 mm long, subsessile to sessile; calyx 2-2.5 mm long, lobate, externally strigose, internally sericeous, lacinias $2-2.5 \times 0.5-0.6 \mathrm{~mm}$, oblong to lanceolate, margin ciliate; corolla ca. $4 \mathrm{~mm}$, obcampanulate, white to violaceous, inner perianth yellow, externally strigose, internally tomentose, tube ca. $1.5-2 \mathrm{~mm}$ long, lobes 1.3-2 $\times 1.5 \mathrm{~mm}$, orbicular, patent, apex obtuse to rounded; stamens 5 , free, subsessile, anthers $1.2 \times 0.5 \mathrm{~mm}$, oval to lanceolate; ovary ca. $1 \mathrm{~mm}$ long, globose, glabrous; style 1, entire, atrophied, stigma 1, ca. $0.7 \mathrm{~mm}$ long, widely conical, sparsely strigose, stigmatic disk ca. 0.1 mm long. Schizocarp 1.8-3 mm long $\times 1.3-1.6$ mm diam., flattened-globose, nutlets 2 , verrucose. Examined material: Cajazeiras, próximo à vila DNOCS, margem de estrada, 11.XII.2014, fl. and fr., F.C.P. Costa 70 (HUNEB).

Heliotropium angiospermum is distributed from the southern United States through Argentina, and in the Antilles (Fröhlich 1981). Occurs in the northeastern and southeastern regions of Brazil that represent its meridional distribution limits (Melo \& Semir 2008; BFG 2018). In the study area occur in anthropogenically impacted areas, on roadsides, and associated with the herbaceous stratum on sandy-clayey soils. Flowering and fruiting in December.

This species can be easily recognized by its scabrous to hirsute branches, stigma widely conical, and fruit subglobose, verrucose.
6. Heliotropium elongatum (Lehm.) I.M.Johnst., Contr. Gray Herb. 81: 18. $1928 . \quad$ Fig. 3e

Subshrub, 15-90 cm tall, erect to decumbent. Branches hirsute. Leaves alternate to subopposite; petiole partially alate, densely hirsute; blade $5.2-6.6 \mathrm{~cm} \times 4.5-5.6 \mathrm{~cm}$, membranaceous, oval to deltoidal, apex acute to acuminate, margin irregular, base attenuated to asymmetrical, adaxial face bowed outward, pubescent to glabrescent, abaxial face scabrous to glabrescent; venation semicraspedodromous. Inflorescences scorpioid, subterminal and axillary; peduncle $0.5-3.5 \mathrm{~cm}$ long, pubescent. Flowers 6-7 mm long, sessile; calyx $1.5-2.5 \mathrm{~mm}$ long, margin ciliate, lacinias 1.5-2.5 mm long, lanceolate; corolla $4-5 \mathrm{~mm}$ long, hypocrateriform to tubular-hypocrateriform, white to violaceous, inner perianth yellow, externally hispid and internally glabrescent, tube 2.5-4.0 $\mathrm{mm}$ long, lobes ca. $1.4 \mathrm{~mm}$ long, orbicular to rounded; stamens 5, free, subsessile, anthers ca. 1 $\mathrm{mm}$, narrowly oblong to lanceolate; ovary ca. 0.5 $\mathrm{mm}$ long, subglobose; style 1, entire, ca. $0.5 \mathrm{~mm}$ long, terminal, conspicuous; stigma 1, ca. $0.3 \mathrm{~mm}$ long, undivided, clavate. Schizocarp 2-2.5 mm diam., mitriform, costate; nutlet 2, 3-4 mm diam., juxtaposed, hispid, nutlets 2, apex slightly dentate. Examined material: Cajazeiras, Parque Ecológico Engenheiro Avidos, próximo à vila DNOCS, margem de estrada, 11.XII.2014, fl. and fr., F.C.P. Costa 71 (HUNEB); 27.X.2015, fl. and fr., F.C.P. Costa 145 (ACAM).

Heliotropium elongatum is a South American species, with records from Argentina, Bolivia, Paraguay, and Uruguay (Johnston 1928); according to BFG (2018) it occurs throughout Brazil. It was encountered in the EAEP growing on sandy-clayey soils, along roadsides, and around bodies of water. Flowering and fruiting in October and December.

This species can be easily recognized by the adaxial face of the leaf blade bowed outward, petiole alate, and fruit mitriform with nutlets juxtaposed.

7. Myriopus salzmannii (DC.) Diane \& Hilger, Bot. Jahrb. Syst. 125(1): 47. $2003 . \quad$ Fig. 3f Shrub, 2-2.5 m, climbing. Branches villous to glabrescent, lenticels brownish. Leaves alternate; petiole ca. $2.7-4.7 \mathrm{~mm}$ long, villous; blade $2.5-3.2 \times 1.1-1.6 \mathrm{~cm}$, membranaceous, oval to elliptic-lanceolate, apex acute to obtuse, margin entire, ciliate, base obtuse to sharp, adaxial face strigose, abaxial face tomentose; venation camptodromous. Inflorescences scorpioid, with branches secundiflorous, united in panicles, 
terminal and internodal; peduncle $0.7-1 \mathrm{~cm}$ long, villous to tomentose. Flowers ca. 4.3-5.3 mm long, sessile to subsessile; calyx ca. 1.5-2 mm long, externally tomentose, internally glabrous, lacinias $1-1.5 \times 0.1-0.2 \mathrm{~mm}$, lanceolate, apex cirrose; corolla 3-4 mm long, tubular, externally sericeous, internally tomentose, tube ca. $2.8-3 \mathrm{~mm}$ long, lobes ca. 1.6-2.4 mm long, linear, patent, involute, apex filiform; stamens 5, fused at apex, sessile, anthers ca. $0.9 \mathrm{~mm}$ long, oval to lanceolate; ovary ca. 1.5 mm long, conical-pyramidal; style 1 , entire, ca. 1.5 $\mathrm{mm}$ long, cylindrical, glabrous; stigma 1, ca. 0.5 $\mathrm{mm}$ long, conical-triangular, pubescent, stigmatic disk ca. 0.5-0.8 mm long. Drupe 3-5 mm diam., flattened-globose, densely hirsute.

Examined material: Cajazeiras, Parque Ecológico Engenheiro Avidos, lado oeste do açude Engenheiro Avidos, margem de estrada, próximo à prainha, 8.I.2015, fl. and fr., F.C.P. Costa 93 (ACAM).

Myriopus salzmannii is endemic to South America, occurring in Argentina, Bolivia, and Paraguay (Johnston 1930); found in northeastern and southeastern Brazil, associated with Cerrado, Caatinga, and Atlantic Forest vegetation (Cavalheiro et al. 2011). In the study area occur in the shrub layer, climbing on other plants, on clayey soils. Flowering and fruiting in January.

This species can be easily recognized by its climbing habit, branches with brownish lenticels, ovary conical-pyramidal, and conical-triangular stigma.

8. Varronia curassavica Jacq., Enum. Syst. P1. 14. 1760 .

Fig. $3 g$

Shrub, 1-2.5 m tall. Branches villous to hirsute, lenticels brownish. Leaves alternate; petiole ca. 0.5-1.6 cm long, tomentose; blade $3-9.5 \mathrm{~cm}$ $\times 1.5-3.5 \mathrm{~cm}$, chartaceous, elliptic to lanceolate, apex acute, margin serrated, base attenuated, adaxial face strigose, trichomes ferruginous, abaxial face pubescent to tomentose; venation semicraspedodromous. Inflorescences spiciform, terminal and internodal. Flowers ca. 4.7-7 mm long, sessile; calyx 3.1-3.6 mm long, campanulate, cream-colored to green, externally pubescent, internally glabrous, lacinias $0.5-1 \times$ ca. $1 \mathrm{~mm}$, oval-lanceolate, apex acute, ciliate; corolla ca. $5 \mathrm{~mm}$ long, infundibuliform to salverform, white to creamcolored, externally and internally glabrous, tube ca. $5 \mathrm{~mm}$ long, lobes 2-2.5 × 1.5-2 mm, oval, reflexed, folded, apex obtuse; stamens 5, free, filaments 1-1.5 mm long, pubescent at base, anthers ca. $1 \mathrm{~mm}$ long, orbicular; ovary ca. $1 \mathrm{~mm}$ long, subglobose, glabrous; style bipartite, ca. $2.5 \mathrm{~mm}$ long; stigmas 4 , ca. $1.5 \mathrm{~mm}$ long, clavate, narrow, villous.

Examined material: São José de Piranhas, Parque Ecológico Engenheiro Avidos, platô da Serra sítio Frade, 10.II.2015, fl., F.C.P. Costa 90 (HUNEB).

Varronia curassavica occurs from Mexico to northeastern South America (Miller 1988). Amply distributed in Brazil and associated with almost all of the phytogeographic domains (BFG 2018). Occurs in the EAEP associated with shrub-arboreal vegetation on clayey soils. Flowering in February.

This species can be recognized by its lanceolate leaf blade, with attenuated base, inflorescence spiciform, and corolla infundibuliform to salverform.

\section{Varronia leucomalloides (Taroda) J.S.Mill.,} Novon 17(3): 374. 2007.

Fig. 3h

Shrub, 1.5-2 m tall. Branches hirsute, with floccose trichomes. Leaves alternate; petiole ca. 2.6-5.3 mm long, tomentose to hirsute; blade 3-6.6 $\mathrm{cm} \times 1.7-2.8 \mathrm{~cm}$, chartaceous, oval to lanceolate, apex acute to attenuated, margin serrated, base cuneate to sharp, adaxial face tomentose to hirsute, abaxial face floccose; venation craspedodromous. Inflorescences glomerule-globose, terminal and axillary. Flowers 4-7 mm long, sessile; calyx 2-3 mm long, campanulate, cream-colored to green, externally floccose, internally glabrous, lacinias $0.8-1.4 \times 0.6-0.8 \mathrm{~mm}$, oval-lanceolate, apex abruptly acuminate; corolla $4-4.5 \mathrm{~mm}$ long, infundibuliform to salverform, white, externally and internally glabrous, tube ca. $2.8-3.7 \mathrm{~mm}$ long, lobes $1-1.5 \times 1.5-2 \mathrm{~mm}$, wide-oval, reflexed, folded, apex obtuse; stamens 5, free, filaments ca. 0.5-1 mm long, villous at base, anthers $0.4-0.6 \times 0.4 \mathrm{~mm}$, oval; ovary ca. $0.8-1.5 \mathrm{~mm}$ long, subglobose, glabrous; style bipartite, ca. 1.5-2 mm long; stigmas 4, ca. $0.7 \mathrm{~mm}$ long, clavate, narrow, villous.

Examined material: São José de Piranhas, Parque Ecológico Engenheiro Avidos, sítio Canto, margem de estrada, 25.III.2015, fl., F.C.P. Costa 97 (ACAM).

Varronia leucomalloides is endemic to Brazil, being recorded only from the northeastern region in the states of Alagoas, Bahia, Ceará, Paraíba, and Pernambuco, in Caatinga s.str. vegetation (BFG 2018). Found in the EAEP associated with open shrubby Caatinga vegetation on clayey-rocky soils. Flowering in March.

Recognized by its glomerulus-globose inflorescence, apex of calyx abruptly acuminate, and principally by the floccose indument present on the branches, leaves, and calyx. 
Lamiaceae Martinov, Tekhno-Bot. Slovar.: 355. 1820.

The Lamiaceae family is represented in the EAEP by six genera and six species: Amasonia campestris (Aubl.) Moldenke, Hypenia salzmannii (Benth.) Harley, Marsypianthes chamaedrys (Vahl) Kuntze, Mesosphaerum suaveolens (L.) Kuntze, Ocimum campechianum Mill. and Vitex orinocensis Kunth.
Amasonia campestris and $V$. orinocensis represent new records for Paraíba state. A. campestris was found inside of the forest in the rainy season. It's a common species in the EAEP. V. orinocensis had previously been collected in Amazonia, where it is widely distributed (Lima \& França 2009) and in the Atlantic Forest (BFG 2018); therefore, this is the first record of $V$. orinocensis for the Caatinga. In the study area, only a few individuals were found both on the edge and inside the forest.

\section{Key to identification of the species of Lamiaceae in the Ecological Park of Engenheiro Avidos}

1. Ovary undivided; style terminal; fruit drupaceous.

2. Compound leaves; dichasia inflorescence, divaricate branches

6. Vitex orinocensis

2'. Simple leaves; pauciflorous inflorescence, dichasia cymes with 1-3 flowers

1. Amasonia campestris

1'. Ovary 4-lobate; style gynobasic; fruit schizocarpic

3. Bracts oval to wide-oval; calyx bilabiate with upper lacinia cymbiform

5. Ocimum campechianum

3'. Bracts elliptic-lanceolate or filiform; calyx campanulate.

4. Bracts elliptic-lanceolate; lacinias of the calyx deltoidal ...... 3. Marsypianthes chamaedrys

4'. Bracts filiform; lacinias of the calyx acute or aristate

5. Inflorescence thrysoid; lacinias of the calyx acute; intumescence in the median region of the internodes 2. Hypenia salzmannii

5'. Inflorescence capituliform; lacinias of the calyx aristate; internodes without intumescence 4. Mesosphaerum suaveolens

1. Amasonia campestris (Aubl.) Moldenke, Torreya 34: 8. 1934.

Fig. 4a-c

Subshrub, 0.5-1 m tall. Branches brown to a vinaceous, subquadrangular, puberulent to pubescent. Leaves simple, congested on the upper median portions of the branches; petiole $1-2 \mathrm{~cm}$, subquadrangular, pubescent to strigose; blade 6.5$14 \times 2-6 \mathrm{~cm}$, membranaceous, bifacial, obovate to oblanceolate, apex acute, margin serrated, base attenuated to cuneate, adaxial face puberulent to glabrescent, abaxial face puberulent, principal nerve prominent. Inflorescences pauciflorous $15-20 \mathrm{~cm}$ long, dichasia cyme 1-3 flowers; peduncle ca. 6.5$10 \mathrm{~cm}$ long, cylindrical to subquadrangular, brownvinaceous, densely pubescent; rachis $7-15 \mathrm{~cm}$ long, cylindrical, brown to vinaceous, pubescent; bracts $1-3 \times 0.5-1.5 \mathrm{~cm}$, membranaceous, oblong to elliptic, adaxial face vinaceous, glabrescent, abaxial face green, puberulent, margin dentate, apex acute or acuminate; bracteole $2-9 \mathrm{~mm}$ long, brown-vinaceous, filiform, pubescent; pedicel 3-7 mm long, brown-vinaceous, pubescent; calyx ca. $0.8-1.2 \times 0.3-0.8 \mathrm{~cm}$, campanulate, membranaceous, greenish with reddish lacinias, externally puberulent, internally glabrescent; lacinias $1.5-2 \times 1-1.5 \mathrm{~mm}$, oval to lanceolate, margin entire, apex acuminate, rarely cirrose; corolla ca. 2.3-3.3 cm long, yellowish; tube 2-2.2 $\mathrm{cm}$ long, externally puberulent, internally glabrous; lobes $2.5-4 \times 1.3-1.9 \mathrm{~mm}$, narrowly elliptic, externally pubescent, internally glabrescent; stamens 4 , inserted ca. $6 \mathrm{~mm}$ from base (the smaller ones) to ca. $5 \mathrm{~mm}$ long from base (the larger ones), filaments ca. $3 \mathrm{~mm}$ long (the smaller ones), ca. 3.3 $\mathrm{mm}$ long (the larger ones), pubescent on the basal portion, anthers ca. $2.5 \times 1 \mathrm{~mm}$; ovary undivided, $2-3 \times 2 \mathrm{~mm}$; style $3-3.3 \mathrm{~cm}$ long, terminal, glabrescent; stigmatic segments ca. $1.5 \mathrm{~mm}$ long (the smaller one), $2 \mathrm{~mm}$ long (the larger one). Drupe immature.

Examined material: São José de Piranhas, Parque Ecológico Engenheiro Avidos, Serra do Frade, trilha na subida da serra, 23.III.2015, fl. and fr., F.C.P. Costa 95 (HUNEB).

Amasonia campestris occurs in Central America (Trinidad and Tobago) and South America (Brazil, the Guianas, Suriname, and Venezuela) (Santos et al. 2012); widely distributed in the northern, northeastern, central-western and 

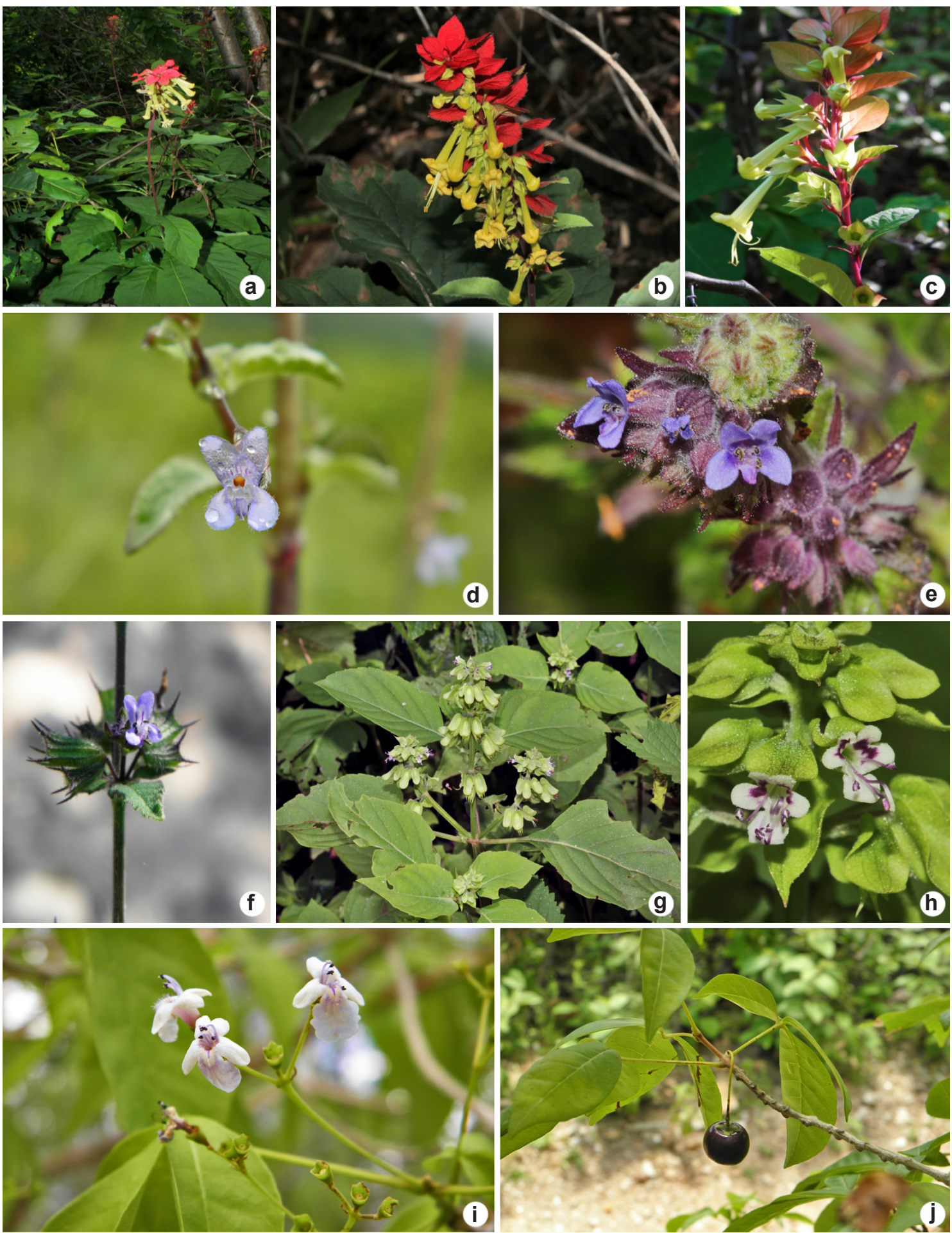

Figure 4 - a-c. Amasonia campestris - a. habit. b. inflorescence. c. inflorescence. d. Hypenia salzmannii - detail of the flower. e. Marsypianthes chamaedrys - inflorescence. f. Mesosphaerum suaveolens - flower and fruit. g-h. Ocimum campechianum - g. habit. h. inflorescence. i-j. Vitex orinocensis - i. inflorescence. j. fruit. 
southeastern regions of Brazil, in Caatinga s.str., Campo rupestre, Cerrado s.l., and "terra firme" forest vegetation (BFG 2018). In the EAEP, this species is associated with shrub-arboreal Caatinga vegetation, occurring in the interiors of shaded areas on sandy/ rocky soils. Flowering and fruiting in March.

This species can be recognized by its pauciflorous inflorescence with dichasium cyme with 1-3 flowers, bracts vinaceous, and calyx apex acuminate to cirrose (rare). It was found in Paraíba state for the first time in this study.

2. Hypenia salzmannii (Benth.) Harley, Bot. J. Linn. Soc. 98: 91. 1988.

Fig. $4 d$

Subshrub, 1.5-2 m tall. Branches cylindrical, violaceous, intumescence in the median portion of the internodes, pubescent to villous. Leaves opposite; petiole 3-6 $\mathrm{mm}$ long, villous; blade ca. 1.2-3.1 × 0.5-1 cm, membranaceous, oval to lanceolate, apex acute, margin crenate, base cuneate, adaxial face pubescent, abaxial face tomentose; venation eucamptodromous. Inflorescences $2-16.5 \mathrm{~cm}$ long, thyrsoid; peduncle 2-10 cm long; bracts ca. $0.5-1 \mathrm{~mm}$ long, filiform, pubescent. Flowers ca. 4.2-7.1 cm long; calyx $2-5.5 \mathrm{~mm}$ long, campanulate, externally pubescent to strigose, lacinias ca. $1.5 \mathrm{~mm}$ long, acute, margin ciliate; corolla violet to blue, 5.5-8 mm long, bilabiate, externally and internally pubescent, lobes of different sizes 3-3.2 mm long, apex rounded; stamens 4, didynamous, smaller filaments ca. 1 $\mathrm{mm}$ long, larger filaments ca. $1.5 \mathrm{~mm}$ long, villous, anthers ca. $0.7 \mathrm{~mm}$ long, ovoid; ovary 4-lobate, ca. $1 \mathrm{~mm}$ diam., globose; style ca. $5.5 \mathrm{~mm}$ long, gynobasic, glabrous; stigma ca. $0.5 \mathrm{~mm}$ long, bifid. Schizocarp ca. 2.5-3 mm long, blackish, oblong, apex acuminate, glabrous.

Examined material: São José de Piranhas, Parque Ecológico Engenheiro Avidos, próximo a córrego, sítio Frade, 14.X.2014, fl. and fr., F.C.P. Costa 58 (HUNEB); 27.VII.2015, fl. and fr., F.C.P. Costa 110 (ACAM); área de pastoreio, sítio Frade, 27.X.2015, fl. and fr., F.C.P. Costa 146 (UFCG-CFP).

Hypenia salzmannii occurs in South America (Brazil, British Guiana, and Venezuela) (Harley 2012); it is found in northeastern and southeastern Brazilian, which corresponds to its southern geographic limit (BFG 2018). According to Santos $\&$ Silva (2009), this species is typical of Caatinga vegetation. It occurs in large populations in the EAEP in open areas and roadsides on sandy or sandy/rocky soils. Flowering and fruiting in July and October.
This species can be easily recognized by its branches violaceous, intumescent, inflorescences in thyrsoid, and calyx with ciliate margins with lacinias acute.

\section{Marsypianthes chamaedrys (Vahl) Kuntze,} Revis. Gen. Pl. 2: 524. $1891 . \quad$ Fig. 4e

Herb, $15-50 \mathrm{~cm}$ tall. Branches quadrangular, narrow to decumbent, sulcate, glandular -pubescent to hirsute, green-vinaceous to brown. Leaves decussate; petiole $0.5-2 \mathrm{~cm}$ long, sulcate, glandular-pubescent; blade 1.5-5.5 × 0.5-3 cm, membranaceous, oval to lanceolate, apex acute, margin crenate-serrated, glandular-ciliate, base cuneate to truncated, both faces sparsely-pubescent; venation brochidodromous. Inflorescences capituliform cymes, 2-4 cm diam.; peduncle 2-3.2 $\mathrm{cm}$ long, tomentose; bracts $6.5-8.4 \times 1.5-2.7 \mathrm{~mm}$, elliptic-lanceolate, apex acute, sparsely-pubescent to glabrescent, margin glandular-ciliate, greenishyellow to brown-vinaceous, bracteole 6.5-7.5 $\times 0.5-1 \mathrm{~mm}$, linear, apex acute to acuminate, pubescent, green to vinaceous; pedicel ca. $1 \mathrm{~mm}$ long, pubescent. Flowers 8-9 mm long; calyx ca. 6.5-7 mm long, campanulate, pubescent, lacinias $2.5-3 \times 1-1.3 \mathrm{~mm}$, deltoidal, apex acute to acuminate, margin glandular-ciliate, intermingled with hirsute indument, with aciculiform trichomes; corolla violet, 7-8 $\mathrm{mm}$ long, hypocrateriform, pubescent in the region of the lobes, lobes 2-2.5 $\mathrm{mm}$ long, margin glandular-pubescent; stamens 4, didynamous, filaments ca. 1.5-2 mm long, tomentose, anthers ca. $0.6-0.8 \mathrm{~mm}$ long, ovoid; ovary 4-lobate, ca. $1 \mathrm{~mm}$ diam., globose; style ca. $6 \mathrm{~mm}$ long, gynobasic, glabrous; stigma ca. 0.3 $\mathrm{mm}$ long, clavate. Schizocarp 2-2.5 × $1.5 \mathrm{~mm}$, light brown, ovate.

Examined material: Cajazeiras, Parque Ecológico Engenheiro Avidos, margem oeste do açude, Prainha, 10.II.2015, fl. and fr., F.C.P. Costa 92 (HUNEB); 18.V.2015, fl. and fr., F.C.P. Costa 100 (UFCG-CFP); margem leste do açude, próximo à parede, 25.III.2015, fl. and fr., F.C.P. Costa 94 (ACAM).

Marsypianthes chamaedrys occurs from southern United States, through Central America, to northeastern Argentina in South America (Harley 2012). This species is distributed throughout Brazil, except in Rio Grande do Sul state (BFG 2018); found in the Amazon and Atlantic forests, Cerrado, Caatinga, and the Pantanal (wetlands), commonly associated with anthropogenically altered areas, although it can be encountered long the margins 
of rivers and streams and in the shadow of tree canopies growing on sandy or clayey soils and on rock outcrops (BFG 2018). It was collected in the study area near the reservoir in altered areas and in Caatinga shrub vegetation on clayey or rocky soils. Flowering and fruiting in February, March, and May.

It's characterized by cuneate to truncated leaf blade base, bracts elliptic-lanceolate, greenishyellow to brown-vinaceous, deltoidal lacinias with acute to acuminate apex, margin glandular-ciliate with hirsute indument with aciculiform trichomes.

4. Mesosphaerum suaveolens (L.) Kuntze, Revis. Gen. P1. 2: 525. 1891.

Fig. $4 f$

Subshrub or shrub, ca. 0.4-2 $\mathrm{m}$ tall. Branches quadrangular, sulcate, internodes without intumescence, strigose to sericeous. Leaves decussate; petiole $0.5-6.5 \mathrm{~cm}$ long, sulcate, pubescent; blade 2-8.7 × 1.3-6.7 cm, membranaceous, oval, apex acute, margin serrated, base cordate, adaxial face sparsely tomentose, abaxial face glabrescent; venation semicraspedodromous. Inflorescences $1.5-2 \mathrm{~cm}$ long, capituliform, axillary; peduncle $0.5-1 \mathrm{~cm}$ long, subquadrangular, pubescent; bracts 1-2.2 mm long, filiform, pubescent. flowers 6-7 cm long; calyx ca. $0.5-1 \mathrm{~cm}$ long, campanulate, externally pubescent, lacinias 2-3.5 mm long, aristate, margin ciliate; corolla violet, 7-8 $\mathrm{mm}$ long, bilabiate, externally pubescent, internally tomentose, lobes ca. 0.7 mm long; stamens 4, didynamous, smaller filaments ca. $2 \mathrm{~mm}$ long, larger ones ca. $3 \mathrm{~mm}$ long, villous, anthers ca. $0.8 \mathrm{~mm}$ long, ovoid; ovary 4-lobate, ca. $0.5 \mathrm{~mm}$ diam., globose; style ca. 6.5 $\mathrm{mm}$ long, gynobasic, glabrous; stigma ca. $0.5 \mathrm{~mm}$ long, bifid. Schizocarp 3-4 mm, blackish, oblong, apex acuminate, glabrous.

Examined material: Parque Ecológico Engenheiro Avidos, margem oeste do açude, Prainha, 12.VII.2014, fl., F.C.P. Costa 24 (HUNEB); margem de estrada próxima à vila DNOCS, 18.V.2015, fl., F.C.P. Costa 105 (ACAM); lado oeste do açude Engenheiro Avidos, 27.X.2015, fr., F.C.P. Costa 113 (JPB); São José de Piranhas, Parque Ecológico Engenheiro Avidos, lado oeste do açude, margem da estrada a barlavento da vertente da serra do Frade, 27.X.2015, fr., F.C.P. Costa 147 (UFCG-CFP).

Mesosphaerum suaveolens is amply distributed throughout the tropical Americas, Asia, Africa, and Australia (Harley 2012). Occurs throughout Brazil, except in the extreme south (BFG 2018). In the EAEP, it was encountered along the roadside and in the forest interior, associated with anthropogenically modified areas and in shrub Caatinga vegetation growing on sandy, clayey, or rocky soils. Flowering and fruiting in May, July, and October.

This species is characterized by capituliform inflorescences, calyx with ciliate margin, lacinias aristate, and filaments villous.

5. Ocimum campechianum Mill., Gard. Dict., ed. 8. n. 5.1768. Fig. 4g-h

Herb or subshrub, 15-50 cm tall. Branches quadrangular, sulcate, green-vinaceous or brown, puberulent. Leaves decussate; petiole ca. 0.3-2.3 cm long, quadrangular, pubescent; blade ca. 2.5-6 $\times 1-3.3 \mathrm{~cm}$, membranaceous, oval, bifacial, apex acute to cuspidate, margin serrated, base attenuated, both faces with punctiform glands; venation eucamptodromous. Inflorescences $1.5-12 \mathrm{~cm}$ long, paniculiform, terminal, lateral branches generally smaller; peduncle 1-3 cm long, quadrangular, puberulent-glandular; bracts ca. 2.5-6 × 2-5 $\mathrm{mm}$, foliaceous, oval to wide-oval, apex acute to caudate, externally punctate-glandular. Flowers 4-7 mm long; calyx at anthesis ca. 1.7-2.5 mm, horizontal, at fruiting ca. $0.7-1 \mathrm{~cm}$ long, slightly reflexed, bilabiate, upper lacinia cymbiform with rounded apex, lateral lacinias with cuspidate apex, lower lacinias narrowly-lanceolate with aristate apex, puberulent to pubescent ventrally, punctateglandular dorsally; corolla white, internally violet, 3-4 mm long, bilabiate, puberulent to pubescent, lobes $1-1.5 \times 0.5-1 \mathrm{~mm}$, upper lobe orbicular, lower lobes oblong; stamens 4, didynamous, filaments ca. $2 \mathrm{~mm}$ long, anthers with divergent capsule, larger ones ca. $0.6 \mathrm{~mm}$ long, smaller ones ca. $0.3 \mathrm{~mm}$ long, ovoid; ovary 4-lobate, ca. $0.4 \mathrm{~mm}$ diam., obovate; style ca. $4 \mathrm{~mm}$ long, gynobasic, glabrous; stigmas of different sizes, largest ones ca. $0.4 \mathrm{~mm}$ long, smallest ones ca. $0.2 \mathrm{~mm}$ long, bifid. Schizocarp 1-1.5 mm, brown, obovate, with mucilaginous contents when humid.

Examined material: Cajazeiras, Parque Ecológico Engenheiro Avidos, lado oeste do açude, margem de estrada sentido sítio Frade, 11.X.2014, fl., F.C.P. Costa 66 (HUNEB); 10.II.2015, fr., F.C.P. Costa 91 (ACAM).

Ocimum campechianum is a Neotropical species with distribution from southern United States to Argentina (Almeida \& Albuquerque 2002); it occurs in all regions of Brazil (BFG 2018). It was encountered in the EAEP on roadsides and on a mountain plateau associated with shrub Caatinga vegetation on sandy-clayey soils. Flowering and fruiting in December and February. 
It's easily identified by having punctiform glands on the leaves, bracts, and calyx as well as foliaceous bracts with acute to caudate apex and upper lacinia cymbiform with rounded apex.

\section{Vitex orinocensis Kunth, Nov. Gen. Sp. 2: 247.} 1818.

Fig. 4i-j

Shrub, 2-3 m tall. Branches subcylindrical to cylindrical, ashen, glabrous, with longitudinal furrows. Leaves opposite, compound; petiole ca. $1.1-4.1 \mathrm{~cm}$ long, subquadrangular, sulcate, pubescent, petiole ca. $0.6-1.8 \mathrm{~cm}$ long; lateral leaflets chartaceous, $2.4-7 \times 1.2-2.5 \mathrm{~cm}$, central leaflet subcoriaceous, ca. $3.5-8.7 \times 1.9-3.5 \mathrm{~cm}$, elliptic, apex acuminate to attenuated, margin entire, base attenuated to cuneate, slightly bifacial, adaxial face glabrous, abaxial face pubescent on the nerves, grayish, central nerve prominent; venation brochidodromous. Inflorescences $4-5 \mathrm{~cm}$ long, forming dichasias, with divaricate branches; peduncle ca. $2.2-3.5 \mathrm{~cm}$ long, subquadrangular, sulcate, strigose. Flowers 6-7.5 cm long; calyx 2-3.1 mm long, campanulate, externally strigose, lacinias ca. $0.3 \mathrm{~mm}$ long, acute; corolla violet, ca $1 \mathrm{~cm}$ long, bilabiate, externally tomentose and internally pubescent in the upper portion of the inner perianth, lobes of different sizes ca. 1.8-5.7 $\times 1.8-4.5 \mathrm{~mm}$; stamens 4 , free, didynamous, small filaments ca. $4.5 \mathrm{~mm}$ long, large ones ca. $6 \mathrm{~mm}$ long, puberulent, basally pubescent, anthers ca. 0.5-1 mm long, ovoid, blackish; ovary undivided, ca. $1 \mathrm{~mm}$ diam., globose; style ca. $6 \mathrm{~mm}$ long, terminal, glabrous; stigma ca. $0.6 \mathrm{~mm}$ long, bifid. Drupe ca. $3 \mathrm{~cm}$ diam., vinaceous, glabrous.

Examined material: Cajazeiras, Parque Ecológico Engenheiro Avidos, lado oeste do açude, margem de estrada sentido sítio Frade, 11.XII.2014, fl., F.C.P. Costa 69 (HUNEB).
Vitex orinocensis is endemic to South America, occurring in Brazil, Colombia, Ecuador, Guyana, French Guiana, Suriname and Venezuela (Funk et al. 2007; Idárraga-Piedrahita et al. 2011). According to Lima \& França (2009), this species shows a principally Amazonian distribution in Brazil, occurring in the states of Acre, Amapá, Amazonas, Maranhão, Mato Grosso, and Pará. It is also known to occur in the states of Bahia and Esprírito Santo associate with Atlantic Forest vegetation (BFG 2018). It was recorded in the study area along roadsides, on steep hillsides, associated with shrub Caatinga vegetation growing on clayey soils. Flowering in December.

This species can be readily identified by its subcoriaceous central leaflet, inflorescence in dichasia, with divaricate branches, as well as anthers blackish.

Verbenaceae J. St.-Hil., Expos. Fam. Nat.: 245. 1805.

The Verbenaceae family is represented in the EAEP by four genera and seven species: Lantana camara L., Lantana canescens Kunth, Lantana fucata Lindl., Lippia alba (Mill.) N.E. Br. ex Britton \& P. Wilson, Lippia grata Schauer, Priva lapullacea (L.) Pers. and Stachytarpheta microphylla Walp.

Two species were recorded for the first time for the Paraíba state: P. lapullacea and S. microphylla. P. lapullacea was found in anthropic areas near ruins and residences, while S. microphylla was collected in humid area during rainy and dry seasons. S. microphylla is endemic to Brazil and according to the BFG (2018) is restricted to the Northeastern region, in the Caatinga domain, occurring only in the states of Bahia and Piauí. $L$. grata is also endemic to Brazil, and occurs in the North and Northeastern regions in dry areas.

\section{Key to identification of the species of Verbenaceae in the Ecological Park of Engenheiro Avidos}

1. Leaves sessile; androecium with 2 stamens and 2 staminoids ............ 7. Stachytarpheta microphylla

1'. Leaves peciolate; androceu with 4 stamens.

2. Inflorescences terminal; calyx inflated on fruit; armed

6. Priva lappulacea

2'. Inflorescences axillary; calyx not inflated on fruit; unarmed.

3. Stigma orbicular or ovate; fruits with 2 pyrenes.

4. Branches aculeate; bracts oblong-lanceolate; flowers orangish, yellow, or red

4'. Branches unarmed; bracts with other shapes; flowers white or violet.

5. Abaxial face of leaf blade canescent; inflorescences with external bracts caudate, internal bracts cirrose; fruit light-brown 2. Lantana canescens

5'. Abaxial face of leaf blade not canescent; inflorescences with external bracts acute to attenuated, internal racts acute; fruit vinaceous 3. Lantana fucata 
3'. Stigma capitate; fruits with 2 nutlets.

6. Calyx with lacinias of apex truncated; corolla violet; ovary elliptic 4. Lippia alba

6'. Calyx with lacinias of apex acute; corolla cream-colored; ovary orbicular 5. Lippia grata

1. Lantana camara L., Sp. Pl. 2: 627. 1753.

Fig. 5a

Subshrub to shrub, 1.5-3 m tall. Branches subcylindrical to quadrangular, aculeate, sulcate, tomentose to hirsute. Leaves decussate; petiole ca. $0.5-2.5 \mathrm{~cm}$ long, quadrangular, pubescent; blade $2-13.5 \times 1.5-8.7 \mathrm{~cm}$, chartaceous, oval, apex acute to acuminate, margin serrated, base truncated, adaxial face scabrous to sericeous, abaxial face tomentose; venation craspedodromous. Inflorescences $1.5-9.3 \mathrm{~cm}$ long, capituliform, axillary; peduncle $1-8.3 \mathrm{~cm}$ long, scabrous to hirsute; bracts ca. 4.5-6.5 mm long, oblonglanceolate, externally hirsute-tomentose, internally hirsutulose, margin ciliate. Flowers ca. $1 \mathrm{~cm}$ long; calyx ca. $1.7 \times 1.3 \mathrm{~cm}$, campanulate, apex truncate, externally pubescent, margin ciliate; corolla yellow to red, ca. $1 \mathrm{~cm}$ long, hypocrateriform, externally puberulent, inner perianth internally pubescent, lobes ca. 1-1.5 $\mathrm{mm}$ long, tube ca. $6.5-7.5 \mathrm{~mm}$ long; stamens 4 , didynamous, anthers ca. $0.5 \mathrm{~mm}$ long, ovoid; ovary ca. $0.5 \mathrm{~mm}$ diam., orbicular; style ca. 1.5-2 mm long, glabrous; stigma ca. $0.5 \mathrm{~mm}$ long, orbicular. Drupe 3-4.5 mm diam., blackish, globose, glabrous, mesocarp succulent, pyrenes 2 . Examined material: Cajazeiras, Parque Ecológico Engenheiro Avidos, lado oeste do açude, trilha a barlavento da serra de Engenheiro Avidos, 11.X.2014, fl. and fr., F.C.P. Costa 09 (HUNEB); margem da estrada, próximo à vila DNOCS, 8.I.2015, fl., F.C.P. Costa 32 (ACAM); lado oeste do açude, margem da estrada, 8.VIII.2015, fl., F.C.P. Costa 107 (JPB); São José de Piranhas, Parque Ecológico Engenheiro Avidos, sítio Frade, 14.X.2014, fl., F.C.P. Costa 47 (UFCG-CFP).

Lantana camara is native to the tropical Americas, occurring in Mexico, Central America, the Caribbean, and South America (Salimena et al. 2009); occurs throughout Brazil, from coastal vegetation to Caatinga, Cerrado, and forested areas (Santos et al. 2009). According to Santos et al. (2009), this species is not very demanding in terms of its substrate, and can be found growing in sandy, clayey, or rocky soils. It was encountered in the EAEP associated with shrub vegetation, forming populations with many individuals in open areas on clayey and rocky soils, being common at forest edges. Flowering and fruiting from December to February and in August.
This species can be identified by having branches aculeate, inflorescence with oblonglanceolate bracts, and blackish fruits with succulent mesocarp.

2. Lantana canescens Kunth, Nov. Gen. Sp. 2: 259. 1818.

Fig. $5 b$

Subshrub, 0.5-1.5 $\mathrm{m}$ tall. Branches quadrangular, ashen, glabrescent to scabrous, unarmed. Leaves decussate; petiole ca. 2.5-5.5 $\mathrm{mm}$ long, sericeous; blade $1-3.5 \times 0.6-2.9$ $\mathrm{cm}$, membranaceous, bifacial, oval to elliptic, apex acute to attenuated, margin serrated, base attenuated, adaxial face sericeous, abaxial face canescent, tomentose; sericeous on nerves; venation craspedodromous. Inflorescences 1-4 $\mathrm{cm}$ long, corymbiform, axillary, 1 or 2 per axil; peduncle $0.5-2.5 \mathrm{~cm}$ long, pubescent to sericeous; bracts sericeous, differentiated, with 2 external wide-oval, ca. 5.3-5.9 $\times 2.1-5.2 \mathrm{~mm}$, apex caudate, internal bracts oval, ca. 3.7-5.7 $\times 1.5 \mathrm{~mm}$, apex cirrose, persistent on fruit. Flowers ca. $1 \mathrm{~cm}$ long; calyx $1 \times 0.6-1 \mathrm{~mm}$, campanulate, 4-lobate, sericeous, margin ciliate; corolla white to violet, ca. $1 \mathrm{~cm}$ long, hypocrateriform, externally puberulent, internally pubescent, lobes ca. $1-1.5 \mathrm{~mm}$ long, tube 6-7 mm long; stamens 4, didynamous, larger filaments ca. $0.4 \mathrm{~mm}$ long, smaller filaments ca. $0.2 \mathrm{~mm}$ long, glabrous, anthers ca. $0.4 \mathrm{~mm}$ long, oblique; ovary ca. $0.5 \mathrm{~mm}$ diam. long, oblong; style ca. $1 \mathrm{~mm}$ long, glabrous; stigma ca. $0.5 \mathrm{~mm}$ long, ovate. Drupe ca. $2 \mathrm{~mm}$ diam., light-brown, ovate, glabrous, without fissure, face striated, pyrenes 2. Examined material: Cajazeiras, Parque Ecológico Engenheiro Avidos, lado oeste do açude Eng. Avidos, próximo à parede, 7.X.2014, fr., F.C.P. Costa 34 (ACAM); margem de estrada sítio Frade, 11.XII.2014, fl., F.C.P. Costa 65 (HUNEB); próximo à vila DNOCS, 25.III.2015, fl. and fr., F.C.P. Costa 96 (UFCG-CFP).

Lantana canescens shows Neotropical distribution, occurring from the Caribbean basin to southern Texas, tropical Florida, Mexico, the Antilles, South America (Sanders 2001); occurs in all regions of Brazil, being found in areas of Amazonian and Atlantic Forest, Caatinga, and Cerrado vegetation (BFG 2018) on sandy or rocky soils. It was encountered in the EAEP associated with shrub vegetation, forming populations with 

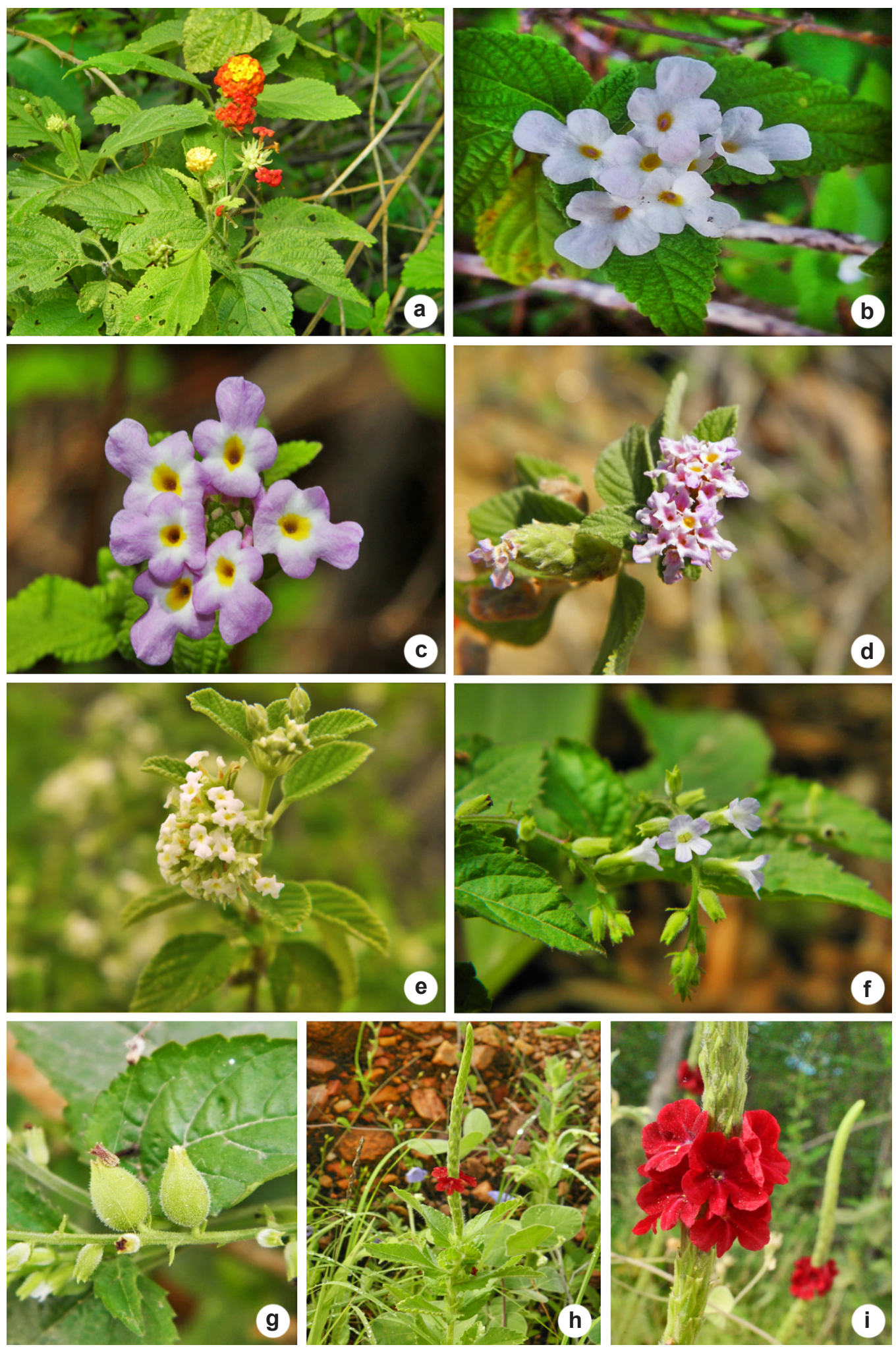

Figure 5 - a. Lantana camara - habit. b. L. canescens - inflorescence. c. L. fucata - inflorescence. d. Lippia alba - inflorescence. e. L. grata - inflorescence. f-g. Priva lappulacea - f. inflorescence. g. fruit. h-i. Stachytarpheta microphyla $-\mathrm{h}$. habit. i. flowers. 
few individuals on clayey and rocky soils, being common along forest edges. Flowering in October and December, and fruiting in March.

This species can be easily recognized by having leaf blades with abaxial faces canescent, inflorescences with two external bracts wide-oval with apex caudate, and internal bracts with apex cirrose, and fruit light-brown, without a fissure.

3. Lantana fucata Lindl., Bot. Reg. 10: t. 798. 1824.

Fig. 5c

Subshrub, ca. 0.5-1.6 m tall. Branches quadrangular, ashen to brownish, glabrescent to scabrous, unarmed. Leaves decussate; petiole 1-3 mm long, sericeous; blade $0.6-2 \times 0.5-1 \mathrm{~cm}$, membranaceous, bifacial, oval to elliptic, apex acute, margin serrated, base attenuated, adaxial face hirtellous to strigose, abaxial face slightly bowed outward, tomentose; venation craspedodromous. Inflorescences $1.5-4.5 \mathrm{~cm}$ long, corymbiform, axillary, 1 per axil; peduncle $0.5-2.7 \mathrm{~cm}$ long, pubescent; bracts sericeous, differentiated into 2 external wide-oval, 5.5-6.2 × 4.9-6 mm, apex acute to attenuated, internal bracts oval to elliptic, $5.1-5.9 \times 2.5-3.6 \mathrm{~mm}$, apex acute, persistent in fruit. Flowers ca. $1 \mathrm{~cm}$ long; calyx $1.3 \times 1$ $\mathrm{mm}$, obcampanulate, apex truncated, sericeous, margin ciliate, expanded in fruit; corolla white to violet, ca. $1 \mathrm{~cm}$ long, hypocrateriform, pubescent externally and internally, lobes of different sizes 1.4-3.6 mm long, tube 6.5-8 mm long; stamens 4, didynamous, filaments ca. $0.4 \mathrm{~mm}$ long, glabrous, anthers ca. $0.7 \mathrm{~mm}$ long, ovate; ovary ca. $0.5-0.7$ $\mathrm{mm}$ diam., oblong; style ca. $1 \mathrm{~mm}$ long, glabrous; stigma ca. $0.5 \mathrm{~mm}$ long, ovate. Drupe ca. $3.5 \mathrm{~mm}$ diam., vinaceous, globose, glabrous, thin fissure, pyrenes 2 .

Examined material: Cajazeiras, Parque Ecológico Engenheiro Avidos, lado oeste do açude, próximo à Prainha, interior da mata, 21.XI.2014, fl., F.C.P. Costa 63 (ACAM); próximo à parede do açude Engenheiro Avidos, 21.XI.2014, fl., F.C.P. Costa 64 (HUNEB); São José de Piranhas, Parque Ecológico Engenheiro Avidos, margem de estrada sentido sítio Frade, 28.VII.2015, fl. and fr., F.C.P. Costa 111 (UFCG-CFP).

Lantana fucata is encountered in temperate, subtropical, and tropical areas in the Americas (Silva 1999); occurring widely in Brazil, with records from the northeastern, central-western, southeastern and southern regions, associated with areas of Caatinga, Cerrado, and Atlantic Forest vegetation (BFG 2018). It was encountered in the EAEP associated with shrub vegetation, forming large populations on sandy, clayey, and rocky soils, common at forest edges. Flowering in November and fruiting in July.

This species can be identified by having leaf blade with abaxial face slightly bowed outward, inflorescence with two external bracts wide-oval with apex acute to attenuated, and internal bracts with apex acute, and fruit vinaceous with thin fissure.

4. Lippia alba (Mill.) N.E. Br. ex Britton \& P. Wilson, Sci. Surv. Porto Rico \& Virgin Islands 6: 141. 1925.

Fig. 5d

Subshrub, ca. $0.5-1.5 \mathrm{~m}$ tall. Branches quadrangular, ashen, pubescent to strigoses. Leaves decussate; petiole $2.5-4 \mathrm{~mm}$ long, pubescent; blade $2-2.5 \times 1-1.5 \mathrm{~cm}$, chartaceous, oval to elliptic, apex acute to acuminate, margin serrated, base attenuated, adaxial face sericeous, abaxial face tomentose; venation campylodromous. Inflorescences 1-3 cm long, spiciform, axillary, 1 per axil; peduncle ca. $0.5-1.3 \mathrm{~cm}$ long, sericeous; bracts villous, orbicular to ovate, external 4.5 $\times 3.5 \mathrm{~mm}$, internal $4 \times 3 \mathrm{~mm}$ apex acuminate, persistent on fruit. Flowers 5-6 mm long; calyx $2 \times 1.5 \mathrm{~mm}$, tubular, apex truncated, tomentose, margin ciliate; corolla violet, 5-6.5 mm long, hypocrateriform, externally and internally villous, lobes of different sizes $0.8-1.8 \mathrm{~mm}$ long, tube ca. 4 $\mathrm{mm}$ long, yellow; stamens 4, filaments ca. $0.3 \mathrm{~mm}$ long, pubescent, anthers ca. $0.4 \mathrm{~mm}$ long, ovate; ovary ca. $0.5-0.9 \mathrm{~mm}$ diam., elliptic; style ca. 1 $\mathrm{mm}$ long, glabrous, dilated until the lower median portion, constriction at base; stigma ca. $0.6 \mathrm{~mm}$ long, capitate. Schizocarp ca. $1.5 \mathrm{~mm}$ diam., 2 nutlets, globose, glabrous.

Examined material: Cajazeiras, Parque Ecológico Engenheiro Avidos, margem oeste do açude Engenheiro Avidos, Prainha, 16.VII.2014, fl., F.C.P. Costa 31 (HUNEB).

Lippia alba is widely distributed in the New World (Sanders 2001), occurring from subtropical areas of South America, the Antilles, to Mexico and the Florida Keys (Florida peninsula); widely found in all of the regions of Brazil, including Caatinga, Cerrado, and the Amazon and Atlantic forests (BFG 2018). In the study area their populations are formed with few individuals near the edge of the reservoir, on clayey-stony soils. Flowering in July.

This species can be easily recognized by its inflorescence spiciform, peduncle sericeous, calyx tomentose with ciliate margin, and corolla violet with yellow tube. 
5. Lippia grata Schauer, Prodr. 11: 576. 1847.

Fig. 5e

Shrub, 1.5-2 m tall. Branches subcylindrical, ashen, glabrescent to strigoses. Leaves decussate; petiole $2-4 \mathrm{~mm}$ long, sericeous; blade $1-1.5 \times$ $0.5-1 \mathrm{~cm}$, chartaceous, oval, apex acute, margin crenate, base cuneate, adaxial face pubescent, abaxial face tomentose; venation craspedodromous. Inflorescences ca. $1 \mathrm{~cm}$ long, spiciform, tetrastic, axillary, 2-4 per axil; peduncle 4-7 $\mathrm{mm}$ long, pubescent to hirsute; bracts concave, plicate, green, tomentose to velvet-like externally, sericeous internally, ovate, external $3.5 \times 2 \mathrm{~mm}$, decussate, persistent on fruit. Flowers $5.5-6.5 \mathrm{~mm}$ long; calyx ca. $1.5 \times 1 \mathrm{~mm}$, tubular, apex acute, shortdentate, margin ciliate, pubescent to tomentose; corolla cream-colored, ca. 5.5-6 mm long, hypocrateriform, externally pubescent, lobes of different sizes 1-1.5 mm long, tube ca. $3.5 \mathrm{~mm}$ long; stamens 4, filaments ca. $0.2 \mathrm{~mm}$ long, anthers ca. $0.2 \mathrm{~mm}$ long, ovate; ovary ca. $0.3 \times 0.2 \mathrm{~mm}$, orbicular; style ca. $1 \mathrm{~mm}$ long, glabrous, stigma ca. $0.2 \mathrm{~mm}$ long, capitate, with lateral papillas. Schizocarp 2-2.5 $\times 0.8 \mathrm{~mm}, 2$ nutlets, narrowovate, brown.

Examined material: Cajazeiras, Parque Ecológico Engenheiro Avidos, platô da Serra Eng. Avidos, ao lado do cruzeiro, 31.III.2015, fl., F.C.P. Costa 98 (HUNEB); 9.VIII.2015, fl. and fr., F.C.P. Costa 120 (ACAM).

Lippia grata occurs in South America, being distributed from northeastern Argentina, through Bolivia, Venezuela, and in the Brazil occurs in the northeastern, northern, central-western and southeastern regions (Santos et al. 2009; O'Leary et al. 2012; BFG 2018). According to Santos et al. (2009), this species occurs in montane forests, Cerrado, and principally in Caatinga vegetation on sandy and clayey soils and rock outcrops. It was encountered in the EAEP on a mountain plateau at $478 \mathrm{~m}$ a.s.l. growing on clayey soils as well as on rock outcrops, forming small populations. Flowering in March and August and fruiting in August.

This species can be recognized by having inflorescence spiciform tetrastic, with bracts concave, plicate, decussate, ovate, tomentose to velvet-like, calyx pubescent to tomentose and corolla cream-colored.

6. Priva lappulacea (L.) Pers., Syn. Pl. 2: 139. 1806.

Fig. $5 \mathrm{f}-\mathrm{g}$

Herb, decumbent or ascendant, ca. 0.3-0.5 $\mathrm{m}$ tall. Branches quadrangular, striate, uncinate- pubescent to glabrescent. Leaves decussate; petiole ca. $0.4-1.2 \mathrm{~cm}$ long, uncinate-pubescent; blade 2.5-6.5 × 1-4 cm, membranaceous, oval to lanceolate, apex acute to acuminate, margin crenate-serrated, base truncated to cuneate, adaxial face strigose, abaxial face puberulent to strigose, trichomes uncinate on nerves and peltate on medial-basal portion, near the central nerve; venation cladodromous. Inflorescences 2-12.5 $\mathrm{cm}$ long, racemes terminal; peduncle $1-2 \mathrm{~cm}$ long, uncinate-pubescent; bracts $1-1.5 \mathrm{~mm}$ long, narrowly oval to lanceolate, apex acute, villous. Flowers 4-6 mm long, pedicelate; pedicel ca. 0.5 $\mathrm{mm}$ long, tomentose; calyx 2-3 mm long, tubular, densely uncinate- hirsutulose intermixed with short trichomes, short-indented, lacinias ca. $0.2 \mathrm{~mm}$ long, apiculate, expanding during fruiting; calyx on fruit inflated, 5-7 × 3-5 mm, oval to urceolate, densely uncinate-hispidulous; corolla white to violet, ca. $5 \mathrm{~mm}$ long, infudibuliform, externally pubescent, internally capitate-pubescent at the insertion of the stamens, lobes $1 \times 1 \mathrm{~mm}$, oblong, apex rounded, tube ca. $3 \mathrm{~mm}$ long; stamens 4 , didynamous, larger stamens inserted in upper half of the tube, filaments ca. $0.6 \mathrm{~mm}$ long, tomentose, anthers ca. $0.7 \mathrm{~mm}$ long, cordate, smaller stamens inserted on the upper third of the tube, filaments ca. $0.5 \mathrm{~mm}$ long, glabrous, anthers ca. $0.4 \mathrm{~mm}$ long, cordate; ovary ca. $1 \times 0.7 \mathrm{~mm}$, ovate; style ca. $0.8 \mathrm{~mm}$ long, glabrous, stigma ca. $0.5 \mathrm{~mm}$ long, lateral. Schizocarp 3.5-4 × 2-3 mm, oblong, osseous, dorsal surface rugose with two parallel rows of rigid thorns, $0.5-1 \mathrm{~mm}$ long.

Examined material: Cajazeiras, Parque Ecológico Engenheiro Avidos, margem de estrada, próximo à vila DNOCS, 18.V.2015, fl. and fr., F.C.P. Costa 103 (HUNEB).

Priva lappulacea occurs from southern United States, Mexico, Central America, the Antilles, to Argentina; it occurs in northern, northeastern, central-western and southeastern Brazil (Nash \& Nee 1984; BFG 2018) associated with Amazonian, Atlantic Forest, and Pantanal (wetlands)- vegetation (BFG 2018), but had not yet been recorded for Caatinga, representing a new occurrence for Paraíba state and Caatinga vegetation in this study. This species was encountered in the EAEP in anthropogenically modified areas near residences going on clayey soils. Flowering in March.

This species demonstrates a number of interesting characteristics, such as the presence of uncinate trichomes on the branches, nerves, 
peduncle, and calyx. The calyx on fruit ovate, fruit oblong with dorsal surface rugose and equinate with two rows of thorns along its margins.

7. Stachytarpheta microphylla Walp., Repert. Bot. Syst. (Walpers) 4: 6. 1845.

Fig. 5h-i

Subshrub, ca. $0.3-1.5 \mathrm{~m}$ tall. Branches rounded to quadrangular, villous, densely at nodes. Leaves decussate, sessile; blade ca. 2.6-5.2 $\times 1-2.5 \mathrm{~cm}$, chartaceous, elliptic, apex acute, margin crenate-serrated, base cuneate, adaxial face villous, abaxial face sparsely villous to glabrescent; venation eucamptodromous. Inflorescences 5-38 $\mathrm{cm}$ long, spiciform, terminal, subsessile, pubescent; bracts 5-8.5 $\times 2-2.5 \mathrm{~mm}$, oblong, apex acuminate, margin ciliate, pubescent at base. Flowers 1-1.5 cm long; calyx ca. $6.1-6.7 \times 0.8 \mathrm{~mm}$, tubular, chartaceous, pubescent, lacinias ca. $1 \mathrm{~mm}$ long; corolla ca. $0.9-1.5 \mathrm{~cm}$ long, red, hypocrateriform, externally glabrescent, internally hirsute in the region of the inner perianth, lobes 3-3.5 $\times$ 2-2.5 mm, tube ca. 5.6-6.3 mm long; stamens 2, filaments ca. $1 \mathrm{~mm}$ long, pubescent, anthers ca. 0.2 $\mathrm{mm}$ long, oblong, staminoids 2 , clavate, pubescent; ovary ca. $1 \times 0.5 \mathrm{~mm}$, mitriform; style ca. $6 \mathrm{~mm}$ long, glabrous; stigma ca. $0.5 \mathrm{~mm}$ long, capitate. Schizocarp $5 \times 1 \mathrm{~mm}$, mitriform, light-brown, deeply embedded in the rachis.

Examined selected material: Cajazeiras, Parque Ecológico Engenheiro Avidos, margem oeste do açude Engenheiro Avidos, Prainha, 16.VII.2014, fl. and fr., F.C.P. Costa 27 (HUNEB); São José de Piranhas, Parque Ecológico Engenheiro Avidos, margem de estrada, sítio Frade, 9.VIII.2015, fl. and fr., F.C.P. Costa 114 (ACAM); trilha na subida da serra do Frade, 9.VIII.2015, fl. and fr., F.C.P. Costa 116 (UFCG-CFP)

Stachytarpheta microphylla is endemic to Brazil, with its occurrence restricted to the northeastern (Alagoas, Bahia, Ceará, Paraíba, Pernambuco, Piauí, Rio Grande do Norte, Sergipe) and southeastern regions of that country (Minas Gerais), in Caatinga s.str., Campo Rupestre, and Cerrado s.l. vegetation (Atkins 2005; BFG 2018). According to Atkins (2005), this species colonizes diverse environments, ranging from disturbed areas to dense Caatinga vegetation. It forms large populations along roadsides in the EAEP, growing on clayey soils and along the edge of the reservoir on sandy-rocky soils. Flowering and fruiting in July and August.

This species can be easily recognized by its sessile leaves, and corolla red.

\section{Acknowledgments}

The authors would like to thank the Universidade Federal de Campina Grande (UFCG) for conceding a permission that facilitated this study accomplishment and for supporting the field and part of laboratory work; the Departamento Nacional de Obras Contra a Seca (DNOCS) for their authorization to undertake collections in the Engenheiro Avidos Ecological Park (PE); the Programa de PósGraduação em Biodiversidade Vegetal, Universidade do Estado da Bahia (PPGBVeg - UNEB); the Laboratório de Botânica (LaBot) da Universidade Estadual da Paraíba (UEPB), Campus I, for their support during the morpho-taxonomic analyses. To Dr. Roy Richard Funch for the English translation of the text. JIM Melo thanks CNPq (Conselho Nacional de Desenvolvimento Científico e Tecnológico) for the Fellowship of Research Productivity (Proc. $n$. 303867/2015-9 (PQ-2)).

\section{References}

Almeida CFCBR \& Albuquerque UP (2002) Check-list of the family Lamiaceae in Pernambuco, Brazil. Brazilian Archives of Biology and Technology 45: 343-353.

Alvares CA, Stape JL, Sentelhas PC, Gonçalves JLM \& Sparovek G (2014) Köppen's climate classification map for Brazil. Meteorologische Zeitschrift 22: 711-28.

Al-Shehbaz IA (1991) The genera of Boraginaceae in the Southeastern United States. Journal of the Arnold Arboretum 1: 1-169.

Angiosperm Phylogeny Group (2009) An update of the Angiosperm Phylogeny Group classification for the orders and families of flowering plants: APG III. Botanical Journal of the Linnean Society 161: 105-121.

Angiosperm Phylogeny Group (2016) An update of the Angiosperm Phylogeny Group classification for the orders and families of flowering plants: APG IV. Botanical Journal of the Linnean Society 181: 1-20.

Atkins S (2005) The genus Stachytarpheta (Verbenaceae) in Brazil. Kew Bulletin 60: 161-272.

BFG - The Brazil Flora Group (2018) Brazilian Flora 2020: innovation and collaboration to meet Target 1 of the Global Strategy for Plant Conservation (GSPC). Rodriguésia 69: 1513-1527.

Cavalheiro L, Ranga NT \& Furlan A (2011) Tournefortia L. (Boraginaceae): espécies do Brasil extraamazônico. Hoehnea 38: 221-242.

Cohen JI (2013) A phylogenetic analysis of morphological and molecular characters of Boraginaceae: evolutionary relationships, taxonomy, and patterns of character evolution. Cladistics 30: 139-169. 
EMBRAPA (2007) Preservação e uso da caatinga. EMBRAPA Informação Tecnológica, Brasília. 39p.

Filgueiras TS, Nogueira PE, Brochado AL \& Guala GF (1994) Caminhamento: um método expedito para levantamentos florísticos qualitativos. Cadernos de Geociências 12: 39-43.

Fröhlich MW (1981) Heliotropium. In: Nash DL \& Moreno NP (eds.) Flora de Vera Cruz 18: 70-84.

Funk V, Hollowell T, Berry P, Kelloff C \& Alexander SN (2007) Checklist of the plants of the Guiana Shield (Venezuela: Amazonas, Bolivar, Delta Amacuro; Guyana, Surinam, French Guiana). Contributions from the United States National Herbarium 55: $1-584$.

Harley RM (1996) The Labiatae of Bahia: a preliminary check-list. Sitientibus, Série Ciências Biológicas 15: 11-21.

Harley RM (2012) Checklist and key of genera and species of the Lamiaceae of the Brazilian Amazon. Rodriguésia 63: 129-144.

Harley RM \& Reynolds T (1992) Introduction. In: Harley RM \& Reynolds T (eds.) Advances in Labiatae Science, London. Pp. 149-166.

Hickey M \& King C (2000) The Cambridge illustrated glossary of botanical terms. Cambridge University Press, New York. 222p.

Idárraga-Piedrahita A, Ortiz RC, Posadas RC \& Merello MC (2011) Flora de Antioquia: catálogo de las plantas vasculares. Universidad de Antioquia, Medellín. 939p.

Johnston IM (1928) Studies in Boraginaceae 7: The South American species of Heliotropium. Contributions from the Gray Herbarium of Harvard University 81: 3-73.

Johnston IM (1930) Studies in Boraginaceae 8: Observations on the species of Cordia and Tournefortia known from Brazil, Paraguay, Uruguay and Argentina. Contributions from the Gray Herbarium of Harvard University 82: 3-89.

Judd WS, Campbell CS, Kellogg EA, Stevens PF \& Donoghue MJ (2009) Sistemática vegetal: um enfoque filogenético. $3^{\mathrm{a}} \mathrm{ed}$. Artmed, Porto Alegre. $632 \mathrm{p}$.

Lima AB \& França F (2007) Flora da Bahia Priva Adans. - Verbenaceae. Sitientibus série Ciências Biológicas 7: 32-35.

Lima AB \& França F (2009) Flora da Bahia: Vitex Tour. ex L. Lamiaceae. Sitientibus série Ciências Biológicas 9: 225-244.

Marx HE, O’Leary N, Yuan YW, Lu-Irving P, Tank DC, Múlgura ME \& Olmstead RG (2010) A molecular phylogeny and alassification of Verbenaceae. American Journal of Botany 97: 1647-1663.

Melo JIM (2012) Flora do Parque Nacional do Catimbau, Pernambuco, Brasil: Boraginaceae sensu lato. Biotemas 25: 109-120.
Melo JIM \& Andrade WM (2007) Boraginaceae s.l. A. Juss. em uma área de Caatinga da ESEC Raso da Catarina, BA, Brasil. Acta Botanica Brasilica 21: 369-378.

Melo JIM \& Semir J (2008) Taxonomia do gênero Heliotropium L. (Heliotropiaceae) no Brasil. Acta Botanica Brasilica 22: 754-770.

Melo JIM \& Semir J (2010) Taxonomia do gênero Euploca Nutt. (Heliotropiaceae) no Brasil. Acta Botanica Brasilica 24: 111-132.

Melo JIM, Silva FKG, Gonçalves MBR, Lima EA, Lucena LAF \& Machado-Filho HO (2011) Boraginaceae sensu lato da Área de Proteção Ambiental (APA) das Onças, São João do Tigre, Paraíba. Biofar: Revista de Biologia e Farmácia 5: 24-33.

Miller JS (1988) A revised treatment of Boraginaceae for Panama. Annals of the Missouri Botanical Garden 75: 456-521.

Nash DL \& Nee M (1984) Verbenaceae: Flora de Veracruz. Instituto Nacional de Investigaciones sobre Recursos Bióticos, Xalapa, Veracruz. Fasc. 41. $154 \mathrm{p}$.

O’Leary N, Calviño CI, Martínez S, Lu-Irving P, Olmstead RG \& Múlgura ME (2012) Evolution of morphological traits in Verbenaceae. American Journal of Botany 99: 1778-1792.

PAE-PB (2011) Programa de ação estadual de combate à desertificação e mitigação dos efeitos da seca no estado da Paraíba. Secretaria de Estado dos Recursos Hídricos, do Meio Ambiente e da Ciência e Tecnologia. Superintendência de Administração do Meio Ambiente - João Pessoa. 186p.

Radford AE, Dickinson WC, Massey JR \& Bell CR (1974) Vascular plant systematics. Harper et Row, New York. 891p.

Salimena FRG, França F \& Silva TRS (2009) Verbenaceae. In: Giulietti AM, Rapini A, Andrade MJG, Queiroz LP \& Silva JMC (orgs.) Plantas raras do Brasil. Conservação Internacional, Belo Horizonte. 496p.

Sanders RW (2001) The genera of Verbenaceae in the southeastern United States. Harvard Papers in Botany 5: 303-358.

Santos JS, França F, Silva MJ \& Sales MF (2012) Levantamento das espécies de Amasonia (Lamiaceae) para o Brasil. Rodriguésia 63: 1101-1116.

Santos JS Melo JIM, Abreu MC \& Sales MF (2009) Verbenaceae sensu stricto na região de Xingó: Alagoas e Sergipe, Brasil. Rodriguésia 60: 985-998.

Santos JS \& Silva JS (2009) Lamiaceae. In: Alves M, Araújo MF, Maciel JR \& Martins S (eds.) Flora de Mirandiba. Universidade Federal de Pernambuco, Recife. Pp. 177-180.

Silva TRS (1999) Redelimitação e revisão taxonômica do gênero Lantana L. (Verbenaceae) no Brasil. 
Tese de Doutorado. Universidade de São Paulo, São Paulo. 176p.

Silva TRS \& Lima CT (2012) Flora da Bahia: Verbenaceae 1: Lantana. Sitientibus, Série Ciências Biológicas 12: 245-268.

Thiers B [continuously updated] Index herbariorum: a global directory of public herbaria and associated staff. New York Botanical Garden's Virtual Herbarium. Available at $<$ http://sweetgum.nybg. org/ih/>. Access on 12 September 2017.

Vieira DD, Melo JIM \& Conceição AS (2015) Boraginales Juss. ex Bercht. \& J.Presl in the Ecoregion Raso da Catarina, Bahia, Brazil. Biota Neotropica 15: 1-17. 